\title{
Latest Ordovician-earliest Silurian chitinozoans from the Puna region, north-western Argentina (Western Gondwana)
}

\author{
G. Susana de la Puente, Florentin Paris \& N. Emilio Vaccarl
}

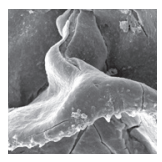

\begin{abstract}
Late Ordovician-early Silurian chitinozoans from the Upper Member of the Salar del Rincón Formation of northwestern Argentina are described. The study area belongs to the Central Andean Basin situated on the western Gondwana margin during the Early Palaeozoic. Chitinozoan assemblages correlate with those from Northern Gondwana, where the effects of the glacial and postglacial events that occurred around the Ordovician-Silurian boundary, are quite welldocumented. The recovered chitinozoan associations from the upper part of the Salar del Rincón Formation record the uppermost Ordovician-lowest Silurian deposits representing the postglacial stage of the late Hirnantian glaciation. Similar strata are usually absent in other parts of the Central Andean Basin. Tasmanites tzadiaensis is recovered for the first time outside of the northeast of Africa, supporting the northern Gondwana affinities. Associated land-derived components indicate a nearshore environment with terrestrial input. The other associated palynomorphs support the latest Hirnantian-earliest Rhuddanian postglacial stage correlation, as well. The ranges of several Late Ordovicianearly Silurian Spinachitina and Cyathochitina species are discussed in terms of the Ordovician-Silurian boundary. Five new species are formally described: Spinachitina titae sp. nov., Cyathochitina brussai sp. nov., Cyathochitina lariensis sp. nov., Cyathochitina punaensis sp. nov. and Ramochitina deynouxi sp. nov. - Key words: chitinozoans, latest Hirnantian-earliest Rhuddanian, Argentine Puna, Argentina.
\end{abstract}

de la Puente, G.S., Paris, F. \& Vaccari, N.E. 2020. Latest Ordovician-earliest Silurian chitinozoans from the Puna region, north-western Argentina (Western Gondwana). Bulletin of Geosciences 95(4), 391-418 (12 figures, 15 tables). Czech Geological Survey, Prague. ISSN 1214-1119. Manuscript received August 19, 2019; accepted in revised form June 5, 2020; published online October 24, 2020; issued November 15, 2020.

G. Susana de la Puente, CITAAC, CONICET - CIGPat, Departamento de Geología y Petróleo, Universidad Nacional del Comahue, Buenos Aires 1400, Q8300IBX, Neuquén, Argentina; susana.delapuente@comahue-conicet.gob.ar • Florentin Paris, Rue des Jonquilles, 35235 Thorigné-Fouillard, France \& Géosciences-Rennes, CNRS UMR 6118, Université de Rennes 1, 35042 Rennes, France • N. Emilio Vaccari, CICTERRA, CONICET-Universidad Nacional de Córdoba. Av. Vélez Sársfield 1611, X5016 GSA, Córdoba, Argentina \& Universidad Nacional de La Rioja. Av. René Favaloro s/n, La Rioja, Argentina

The Central Andean Basin is one of the most important Lower Palaeozoic basins of Western Gondwana (Robin et al. 2004), because of its geographical extent and fossil record. The southern end of this basin is located in north-western Argentina and its outcrops are exposed in the geological provinces of Puna, Cordillera Oriental, Sierras Subandinas and Sistema de Santa Bárbara (Fig. 1A) (Ramos 1999). In the eastern and central part of the basin, the Upper Ordovician is classically represented by the "Zapla Glacial Horizon" (Schlagintweit 1943) of late Hirnantian age (Monaldi \& Boso 1987, de la Puente \& Rubinstein 2013, Benedetto et al. 2015), which is locally called the Mecoyita Formation (Turner 1960) or Caspalá Formation (Starck 1995). This glacial horizon is deposited above the Ocloyic regional discordance, which separates it from the Lower and Middle Ordovician strata. The Zapla Glacial Horizon includes three facies associations: massive matrix-rich diamictites, finely stratified diamictites, and graded sandy and conglomerate beds covering the diamictites facies (Astini 2008). It is overlain by transgressive deposits of the Silurian Lipeón Formation (Turner 1960). In the eastern part of the basin, chitinozoan assemblages document a late Hirnantian age for the glacial deposits and support a basal Silurian age assignment for the strata representing the postglacial sequences in a condensed section (de la Puente et al. 2012, de la Puente \& Rubinstein 2013, Benedetto et al. 2015). In the central part of the basin, chitinozoan assemblages document a Hirnantian age for the glacial deposits and a Telychian age for the postglacial sequences (Rubinstein et al. 2016).

Within the Lower Palaeozoic deposits of western Puna region, in the western part of the basin, no direct sedimentological evidence for glaciation has been found. 
The Ocloyic discordance has a strong angularity and represents an important Ordovician hiatus. In this area, our investigations of chitinozoan associations from the Upper Ordovician-lower Silurian deposits of the Salar del Rincón Formation have been carried out to improve the age for this formation. Preliminary results have been mentioned earlier (de la Puente 2009, Vaccari et al. 2010, de la Puente \& Rubinstein 2013).

Chitinozoans from the latest Hirnantian-earliest Silurian have been documented from different regions of Northern Gondwana and Laurentia (Achab 1981; Asselin et al. 1989; Paris et al. 1998, 2012, 2015; Bourahrouh et al. 2004; Ghavidel-Syooki 2008; Butcher 2009, 2013; Vandenbroucke et al. 2009; Butcher et al. 2010; GhavidelSyooki et al. 2011; Le Hérissé et al. 2013; Thusu et al. 2013). The present study deals with the chitinozoan assemblages from the Argentine Puna region and their sedimentary succession. The focus of this work is to describe in extenso the chitinozoan systematics and their biostratigraphy with in addition phytoplankton data from the Upper Member of the Salar del Rincón Formation.

\section{Geological setting}

The geological region of Puna (Turner 1970) in northwestern Argentina is limited by the Cordillera Occidental (Chile) to the west and the Cordillera Oriental to the east (Fig. 1A). As a result of the Andean Orogenic Cycle since the late Mesozoic, it constitutes at present a high plateau (3,700 m AMSL) structured by huge thrusts and characterized by Cenozoic volcanism and evaporate deposits (Ramos \& Coira 2008). In the south-western Puna, Palaeozoic sedimentary and volcanic deposits are exposed along the Quebrada de Lari (Lari Creek), also called Quebrada del Médano, a western tributary of the salt lake Salar del Rincón (Fig. 1B-F).

The samples studied for palynology come from the type section of the lower Palaeozoic Salar del Rincón Formation (Aceñolaza et al. 1972) exposed on the northeastern flank of the Cerro Oscuro (Oscuro Mountain) (Fig. 1C-F). The Salar del Rincón Formation yields Late Ordovician-early Silurian brachiopods and bivalves (Benedetto \& Sánchez 1990), cryptospores (Rubinstein \& Vaccari 2004) and graptolites (Vaccari et al. 2010). The formation is composed of two members (Donato \& Vergani 1985). The Lower Member (ca. $38 \mathrm{~m}$ thick) has been interpreted as a proximal anastomosed fluvial depositional system, with a supply area situated close to the east. The Upper Member ( $c a .78 \mathrm{~m}$ thick) has been interpreted as a siliciclastic coastal marine facies with terrestrial input (Donato \& Vergani 1985). Although the contact between the two members of the Salar del Rincón Formation has been previously considered as transitional (Donato \& Vergani 1985), the coastal marine Upper Member deposits could represent an erosive event developed on the conglomerate and cross-bedded sandstones of the Lower Member deposits (Figs 1E, F; 2).

An angular unconformity occurs at the contact of the Salar del Rincón Formation with the underlying Las Vicuñas Formation (Moya et al. 1993). The Las Vicuñas Formation has been assigned to the early Tremadocian based on conodont, graptolite and trilobite records (Rao et al. 2000, Vaccari et al. 2010). The Salar del Rincón Formation is overlain by the upper Palaeozoic Cerro Oscuro and Arizaro formations (Aceñolaza et al. 1972), again by angular discordance (Fig. 2).

\section{Material and methods}

Twenty-eight samples were collected in the outcrops of the Upper Member of the Salar del Rincón Formation (Figs 1E, F; 2), and prepared for palynology. Thirteen samples contained identifiable chitinozoans (repository code numbers: 9389, 9396, 9399, 9404-9405, 94079408, 9411-9412, 9415-9416, 9420 and 9423). Remains of chitinozoans were also recovered from seven other samples, but they were not viable for identification to species level (9388, 9406, 9409-9410, 9413, 9418-9419); eight samples are barren of chitinozoans (Fig. 2).

The lithology is dominated by siliciclastic sediments ranging from strongly bioturbated grey to greenish-grey shales to bedded quartz sandstone, massive or bioturbated.

The strongly bioturbated grey to greenish-grey shales constitute the lower and middle part of the Upper Member (Fig. 2). This part of the section (samples 9388 to 9420) shows an upward coarsening grain size trend and thickening of the beds, terminating in that part with siltstone to sandstone beds. The sandy interval ends with a bedded quartz sandstone, in some cases massive, in others bioturbated.

The uppermost part of the section (samples 9421 to 9428), which is mostly covered by debris, is an alternation of silty layers with shaley ones. A ferruginous bed terminates the succession (Fig. 2).

Around 20 grams per sample were processed to recover the palynomorphs. Samples were processed using chitinozoan $\mathrm{HCl}-\mathrm{HF}-\mathrm{HCl}$ acid maceration techniques based on Paris (1981). The organic residue was sieved using a $40 \mu \mathrm{m}$ sieve, and again on $10 \mu \mathrm{m}$ sieve, to remove fine organic particles. All chitinozoans were hand-picked from that residue.

The chitinozoans were picked from the residue using a finely drawn pipette and mounted on stubs for scanning electron microscope (SEM) examination both according to the technique described by Paris (1981). The SEM photomicrographs were taken with four different 


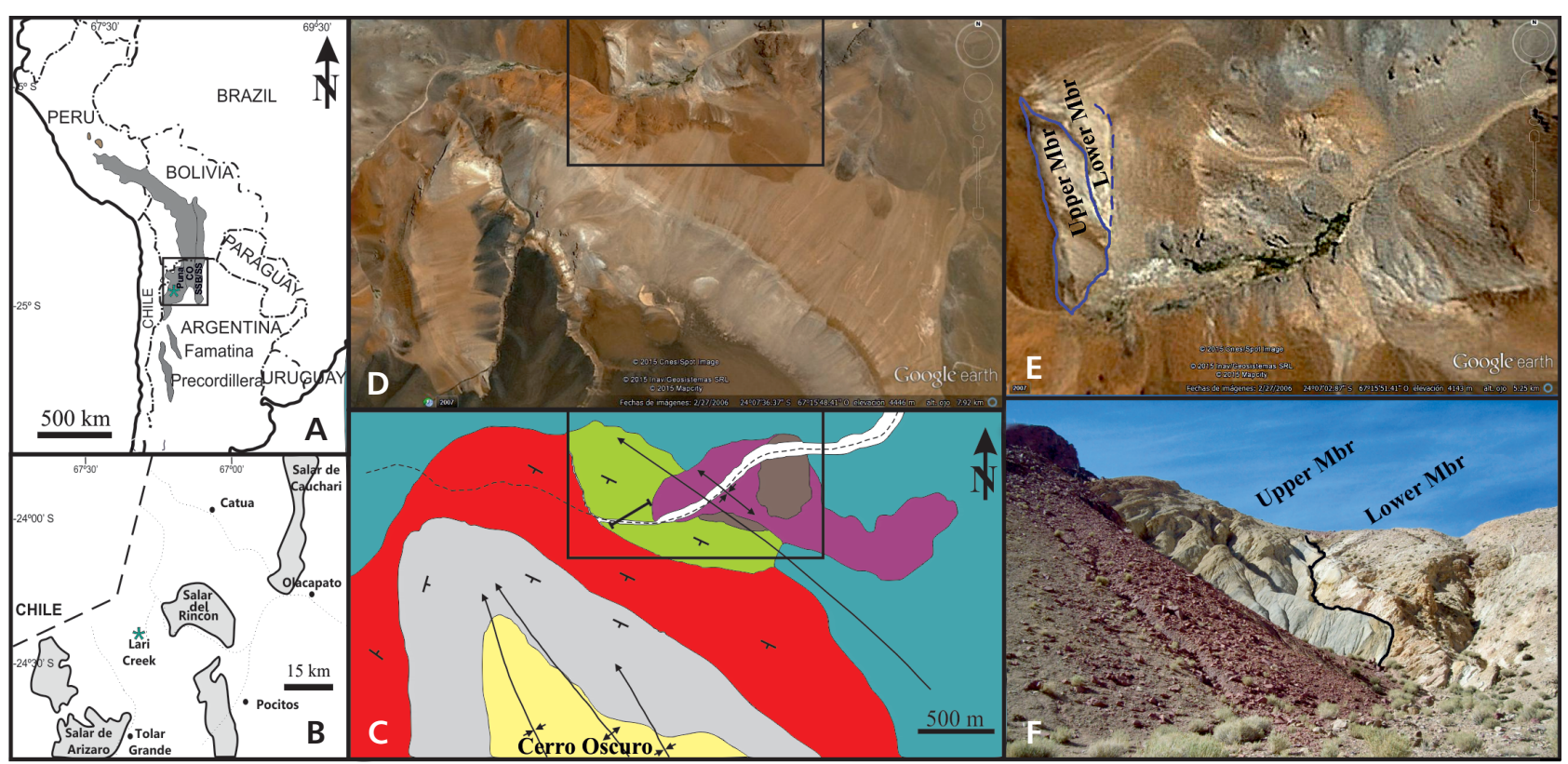

\section{Legend (C)}

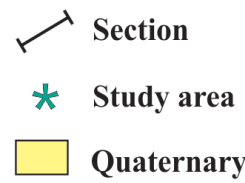

Cenozoic ignimbrite

Arizaro Fm. (Permian)

Cerro Oscuro Fm. (upper Carboniferous)
Salar del Rincón Fm.

(uppermost Ordovician-lowest Silurian)

Ordovician intrusive

Las Vicuñas Fm. (lower Tremadocian)

Figure 1. A - location map of north-western Argentina indicated by a rectangle that includes the geological provinces of Puna, Cordillera Oriental (CO), Sierras Subandinas (SS), and Sistema de Santa Bárbara (SSB). The study area is indicated by an asterisk. • B - location map showing the study area of the Lari Creek in south-western Puna, indicated by an asterisk. $\bullet \mathrm{C}$ - schematic geological map of the study area (that is marked with an asterisk in Fig. 1B) on the north-eastern flank of the Cerro Oscuro (Oscuro Mountain). The rectangle indicates the Lower Ordovician strata and the location of the study stratigraphic section. $\bullet$ D - satellite image of the same area as Fig. 1C where the Salar del Rincón Formation occurs (Google Earth, 2016). E - enlargement of the rectangular inset on Fig. 1D with the Upper Member of the Salar del Rincón Formation indicated. $\bullet F-$ photographs of the outcrop of the Salar del Rincón Formation in the study area at the place of the section indicated in Fig. 1C (GPS coordinate: $24^{\circ} 7^{\prime} 4.73^{\prime \prime} \mathrm{S}, 67^{\circ} 16^{\prime} 0.39^{\prime \prime} \mathrm{W}$ ).

machines: a Philips (XL30 TMP) at the Laboratorio de Microscopía Electrónica, MACN (Museo Argentino de Ciencias Naturales), Buenos Aires, a LEO (1450VP) at the LABMEM (Laboratorio de Microscopía Electrónica y Microanálisis), UNSL-CCT, San Luis, a Philips (515), IB-Centro Atómico Bariloche, and a JEOL (JSM6490LV) SEM at the MEByM (Microscopía Electrónica de Barrido y Microanálisis con EDS), CCT, Mendoza. The material is housed in the collection of the Palaeopalynology Unit of the IANIGLA, CCT, Mendoza and labelled MPLP (Mendoza-Paleopalinoteca-Laboratorio de Paleopalinología).

\section{Biostratigraphy}

\section{Macrofauna}

The age of the Salar del Rincón Formation is considered to span the Ordovician-Silurian based on the fossil macrofauna, which includes the brachiopods Dalmanella sp., Heterorthella sp., Fardenia sp., ?Aphanomena sp., Cryptothyrella cf. C. crassa, and the bivalve Modiomorpha sp. They all have an Argentine Precordilleran and South African affinity (Benedetto \& Sánchez 1990). In the upper part of the formation, the graptolite genus Normalograptus sp. was also recorded (Vaccari et al. 2010) (sample 9421; Fig. 2).

\section{Non-chitinozoan palynomorphs}

A cosmopolitan cryptospore assemblage recorded at the base and the top of the Upper Member of the Salar del Rincón Formation is indicative of the OrdovicianSilurian (Rubinstein \& Vaccari 2004). The species described include Segestrespora laevigata Burgess, 1991, Imperfectotriletes patinatus Steemans et al., 2000 and Laevolancis chibrikovae Steemans et al., 2000. Recent reports from other Gondwanan regions, such as northeast 
of Africa (northern Chad and south-eastern Libya), central Saudi Arabia and northeast of Iran, restrict the age to the Late Ordovician-earliest Silurian (Rhuddanian) (Le Hérissé et al. 2013, Wellman et al. 2015, Ghavidel-Syooki 2017). The euglenid protozoan Moyeria cabottii (Cramer) Miller \& Eames, 1982, recorded in the lower part of the Upper Member of the Salar del Rincón Formation (Rubinstein \& Vaccari 2004), is a common component in the assemblages from the uppermost Hirnantian-lowest Rhuddanian postglacial deposits from northern Chad, south-eastern Libya and Saudi Arabia (Le Hérissé et al. 2013, Thusu et al. 2013). The presence of Moyeria cabottii indicates also freshwater influences (Dorning \& Harding 1998, Le Hérissé et al. 2013, Strother et al. 2019). The prasinophycean phycomata Tasmanites tzadiaensis Le Hérissé et al., 2013, with characteristic solid verrucae (Fig. 9I) is also present in the lower part of the section (sample 9408). Tasmanites tzadiaensis has been recorded in the postglacial deposits of latest Hirnantian-earliest Rhuddanian age in northeast Africa, representing a possible marker for the nearshore environment of the Tanezzuft Formation from south-eastern Libya and northern Chad (Le Hérissé et al. 2013, Thusu et al. 2013). The Puna founding is the first record of Tasmanites tzadiaensis outside of north-eastern Africa.

\section{Chitinozoans}

The chitinozoan association from the lower part of the Upper Member of the Salar del Rincón Formation (samples 9488-9412; Fig. 2) is characterized by abundant Spinachitina verniersi Vandenbroucke et al., 2009, Cyathochitina brussai sp. nov., Cyathochitina aff. C. brussai and Cyathochitina lariensis sp. nov. Spinachitina verniersi is particularly abundant in the middle of this lower part (samples 9407 and 9408). Few Spinachitina cf. S. oulebsiri Paris et al., 2000 and Sphaerochitina aff. S. solutidina Paris, 1988, which extend upward in the section, are also present. Ancyrochitina sp., with broken processes, is dominant in the lower part of the unit (sample 9396), but not at the base. Spinachitina $\mathrm{cf}$. S. oulebsiri, with longer spines than typical specimens of Spinachitina oulebsiri, is associated with transitional forms to Spinachitina verniersi, Spinachitina aff. $S$. verniersi characterized by more numerous spines than Spinachitina verniersi, and with Ramochitina deynouxi sp. nov. The latter is rare in the lower and middle levels but abundant upward in the section (Fig. 2).
Spinachitina titae sp. nov. is rare in the lower part of the section but becomes abundant in the middle part (sample 9415 and 9416), associated with Spinachitina cf. S. oulebsiri, Angochitina sp. and common Acyrochitina cf. A. prima Bouché, 1965 (sample 9415), and the large specimens of Cyathochitina aff. C. brussai (sample 9416).

A different chitinozoan association is observed below the base of an eight meter thick, lenticular coarsegrained sandstone bed (sample 9420). Representatives of the genera Spinachitina and Cyathochitina are practically absent in this level. A single incomplete specimen bears comparatively longer processes and is assigned to Spinachitina cf. S. oulebsiri. Specimens of Ancyrochitininae (Fig. 11O-Q) appear in the uppermost sample of the lower part of the section (sample 9412) but they are dominant in this level with Ramochitina deynouxi sp. nov. and Cyathochitina punaensis sp. nov. (sample 9420). This level also contains rare Sphaerochitina aff. S. solutidina, Belonechitina $\mathrm{cf}$. B. pseudarabiensis Butcher, 2009, and scolecodonts.

In the upper part of the coarse-grained deposits, a bioturbated sandstone that yields the Normalograptus sp. is present. No chitinozoans have been found in this level (sample 9421). Abundant Ramochitina deynouxi sp. nov., few Cyathochitina punaensis sp. nov., Cyathochitina cf. C. caputoi da Costa, 1971 and broken Ancyrochitininae individuals (Fig. 11N) are identified in the uppermost chitinozoan-bearing level of the section (sample 9423). It is taken from a shaley layer in the section between bedded and bioturbated sandstone beds. The specimens are poorly preserved. They are usually incomplete, and their vesicle surfaces are eroded, which make the identification difficult, even at generic level. The uppermost part of this section shows an increasing grain size and ends with a ferruginous bed barren of chitinozoans (sample 9428).

Spinachitina species occurring around the OrdovicianSilurian boundary have been discussed in detail (Paris et al. 2000, 2012; Bourahrouh 2002; Butcher 2009, 2013; Vandenbroucke et al. 2009; Butcher et al. 2010; GhavidelSyooki et al. 2011; Thusu et al.2013), although there is not a general consensus about their lineage or biostratigraphic potential. The Puna specimens assigned to Spinachitina verniersi are close to those defined from the Soom Shale Member of the Cedarberg Formation of South Africa (Vandenbroucke et al. 2009) and dated as latest Hirnantian to probably earliest Rhuddanian in age (see discussion in Thusu et al. 2013). Specimens considered here equivalent to Spinachitina verniersi from Puna are reported from the latest Hirnantian of Northern England (Vandenbroucke

Figure 2. Stratigraphic column of the Salar del Rincón Formation from the study area with photographs of the outcrops where the section has been sampled. The stratigraphic ranges of the chitinozoans encountered are also indicated with the number of specimens recovered per each 20 gram sample of the rock processed. 


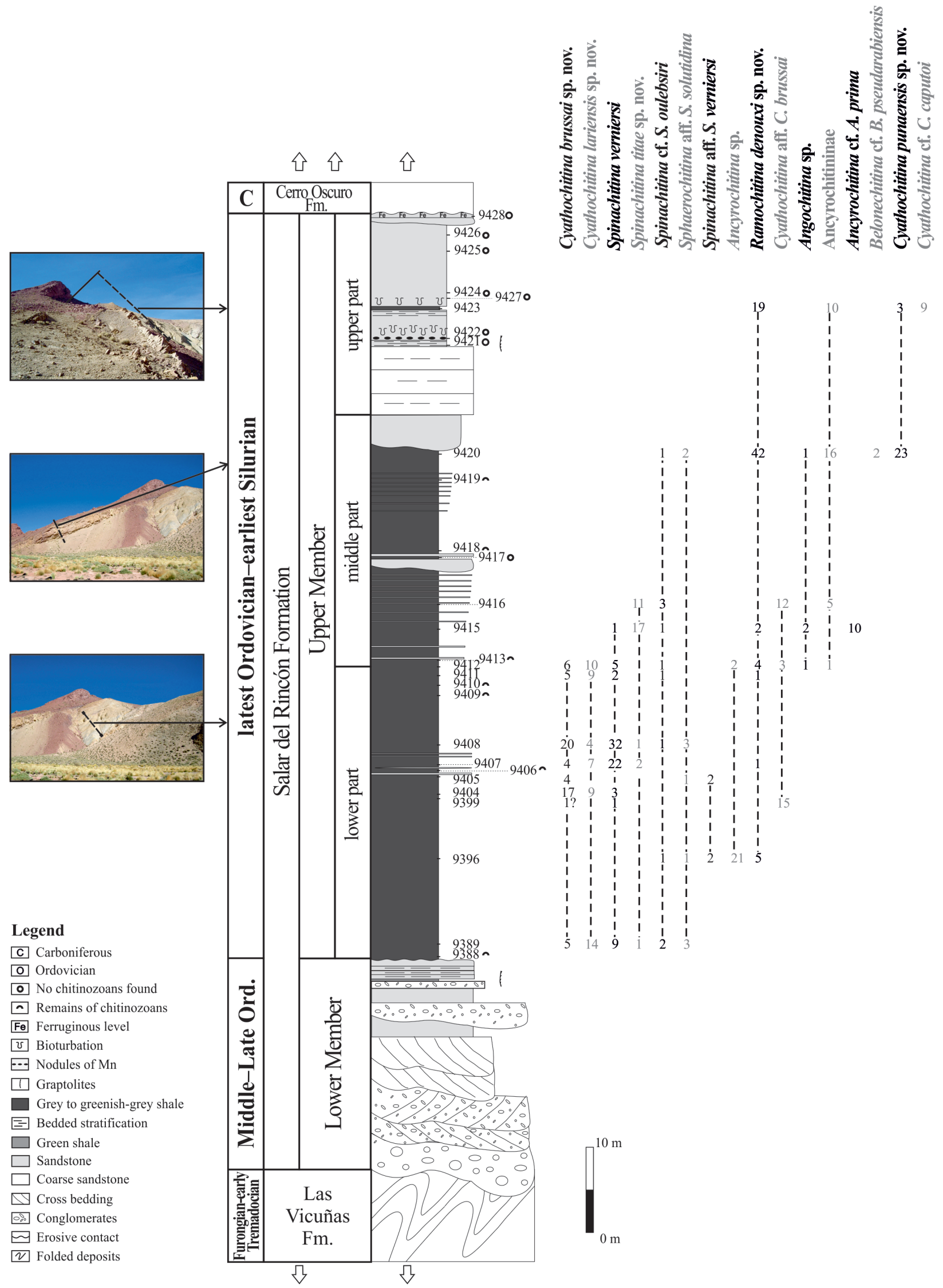


et al. 2005), Wales (Vandenbroucke et al. 2008), Algerian Sahara (Paris et al. 2000), Morocco (Bourahrouh et al. 2004), Iran (Ghavidel-Syooki et al. 2011), and from the Late Ordovician-?earliest Silurian of Chad and Libya (Le Hérissé et al. 2013, Thusu et al. 2013). Spinachitina verniersi is associated with Tasmanites tzadiaensis and Moyeria cabottii in the basal Tanezzuft Formation in northern Chad (Le Hérissé et al. 2013). Spinachitina oulebsiri is frequently regarded as the index species for deposits of late Hirnantian age in northern Gondwana (Paris et al. 2000, Bourahrouh et al. 2004, Webby et al. 2004, Bergström et al. 2009, Ghavidel-Syooki et al. 2011), although it can probably range into the earliest Rhuddanian (see discussion in Vandenbroucke et al. 2009 and Thusu et al. 2013). In north-western Argentina, incomplete specimens with usually eroded spines are provisionally attributed to Spinachitina oulebsiri. Spinachitina cf. $S$. oulebsiri is recorded in the Hirnantian Zapla Formation of the Capillas River in the Sierras Subandinas (Fig. 1A) (de la Puente et al. 2012, de la Puente \& Rubinstein 2013, Benedetto et al. 2015). It is associated with Desmochitina minor form typica Eisenack, 1958, Hercochitina spp., and Belonechitina spp. in a thin interval of dark green to black shales that is present between graded sandy beds above the massive glacially derived diamictite, and also from a highly organic-rich black shale at the very top of the unit.

Cyathochitina brussai sp. nov. is abundant in the uppermost Hirnantian-lowest Rhuddanian from the lowest part (samples NSE 9 to 18) of the Nseirat section from Mauritania (F. Paris, unpublished data).

Ancyrochitininae from Puna cannot be identified to the species level because the processes are incomplete (Fig. 11O-Q). However, their vesicle resembles Plectochitina specimens such as Plectochitina $\mathrm{cf}$. P. pseudoagglutinans from Libya (Butcher 2013) and Plectochitina sp. from Arabia (Paris et al. 2015), which are common in the Rhuddanian.

Belonechitina pseudarabiensis Butcher, 2009 is recorded in the lowest to middle Rhuddanian of northern Gondwana regions (Butcher 2009, 2013; Paris et al. 2015). It is also reported in the latest Hirnantian-earliest Rhuddanian of the lowest part of the Nseirat section from Mauritania, where it occurs with Ramochitina deynouxi sp. nov. and abundant Cyathochitina brussai sp. nov. (F. Paris, unpublished data).

Cyathochitina caputoi da Costa, 1971 is a typical component of the Rhuddanian associations. It is notably abundant in the earliest Rhuddanian of northern Gondwana, preceding the first appearance of Spinachitina fragilis (Nestor, 1980) (Paris et al. 1998, 2015). In the Capillas River area of the Sierras Subandinas (Fig. 1A), an assemblage which includes Cyathochitina caputoi da Costa, 1971 and Spinachitina fragilis (Nestor, 1980) has been observed in a greenish silty-shale that overlies a basal transgressive conglomerate of the Lipeón Formation in the area (de la Puente et al. 2012). The association indicates that the deposition of the lower part of the Lipeón Formation could start in the early Rhuddanian in the eastern part of the Central Andean Basin. In the Caspalá area of the Cordillera Oriental (Fig. 1A) in the central part of the basin, the lower half of the Lipeón Formation is strongly bioturbated. It also contains Cyathochitina gr. caputoi da Costa, 1971 however it is associated with Telychian species (Rubinstein et al. 2016).

\section{Systematic palaeontology}

Chitinozoa are described following the taxonomy and morphological terminology proposed by Paris et al. (1999). Measurements are given in micrometers $(\mu \mathrm{m})$ and their values are expressed in the following order: minimum (mean) maximum; $n$ is the number of measured specimens. Abbreviations used: $\mathrm{L}$ - total vesicle length; Lp - chamber length; Ln - oral tube length; Dp maximum chamber diameter; da - oral tube diameter; $\mathrm{dn}$ - neck diameter; lcoll - collarette length; lcar - carina length; tcar - carina thickness; lsp - spine length.

Group Chitinozoa Eisenack, 1931

Order Prosomatifera Eisenack, 1972

Family Conochitinidae Eisenack, 1931, emend. Paris, 1981

Subfamily Belonechitininae Paris, 1981

\section{Genus Belonechitina Jansonius, 1964}

Type species. - Conochitina micracantha subsp. robusta Eisenack, 1959.

Figure 3. Latest Ordovician-earliest Silurian chitinozoans from the Salar del Rincón Formation, Lari Creek, western Puna. Scale bar $=50 \mu m$; $10 \mu \mathrm{m}$ for B2, C2, E2, and G2. • A - Belonechitina cf. B. pseudarabiensis Butcher, 2009. Specimen with randomly distributed simple spines, longer as hair-like in the chamber but shorter to granules on the neck. Sample 9420. • B-G - Spinachitina cf. S. oulebsiri Paris et al., 2000 ; B1 - broken specimen with simple spines in a crown on the margin, sample 9389; B2 - detail of the margin showing slender, conical spines, sample 9389; $\mathrm{C} 1$ - broken specimen with a conical chamber and smooth vesicle surface; C2 - detail of the margin showing well-developed, but corroded spines, sample 9416; D - incomplete specimen with corroded spines, sample 9416; E1 - broken specimen with robust simple spines, longer than those of Spinachitina oulebsiri, sample 9420; E2 - detail of the base showing the crown of long and wide spines, sample 9420; F - specimen with welldeveloped but broken spines in a crown on the rounded margin, sample 9412; G1 - incomplete specimen with well-developed conical spines surrounded by granules on the margin, sample 9415; G2 - detail of the ornamentation, sample 9415. 

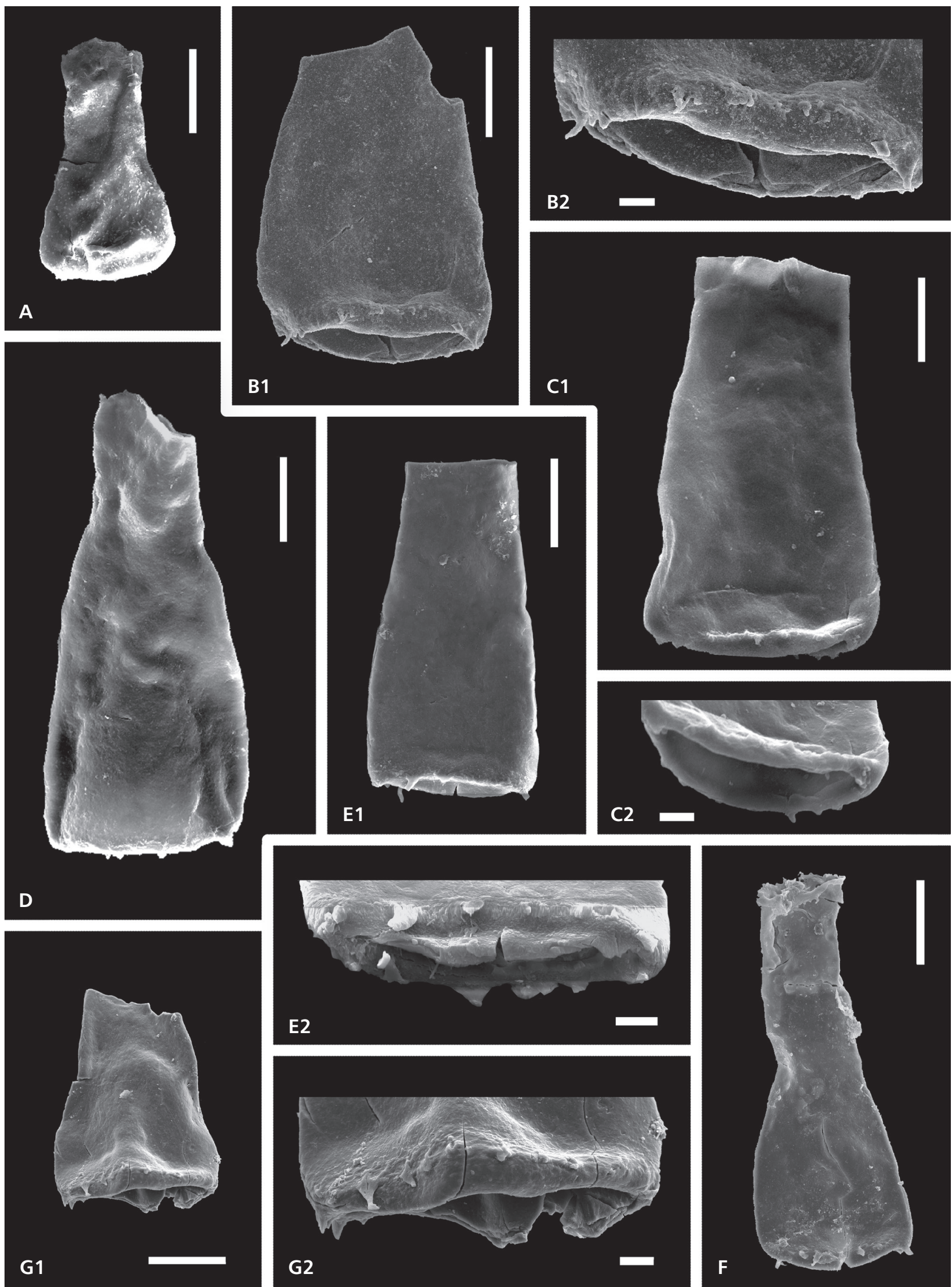
Belonechitina cf. B. pseudarabiensis Butcher, 2009

Figure 3A

Material. - Two specimens from sample 9420.

Dimensions. - See Tab. 1.

Description and discussion. - The chitinozoans have a conical chamber and cylindrical neck (Fig. 3A). The apertural end is missing on both specimens, therefore, the collarette is not observed as is the total length of the individuals $(\mathrm{L} \sim 150 \mu \mathrm{m})$. For this reason, they are provisionally attributed to Belonechitina pseudarabiensis Butcher, 2009. The flanks are straight to slightly convex. The flexure is distinct, and the shoulders are weak. The base is flat, and the margin is broad and round. The wall of the vesicle is covered by randomly distributed simple spines, more prolonged (hair-like) on the chamber and shorter to granulate on the neck.

Occurrence. - Belonechitina pseudarabiensis is described from the lower to middle Rhuddanian (ascensusacuminatus to vesiculosus graptolite biozones) from the Mudawwara Formation (cores WS-6 and BG-14) of southern and eastern Jordan (Butcher 2009). It is also recorded in the middle Rhuddanian of the Murzuq Basin (core E1-NC174), south-western Libya (Butcher 2013), and the lowest Rhuddanian of the basal Qusaiba Member of the Qalibah Formation (core Qusaiba-1), North Central Saudi Arabia (Paris et al. 2015). It is observed in the uppermost Hirnantian-lowest Rhuddanian of the Nseirat section from Mauritania (F. Paris, unpublished data). The two Belonechitina cf. B. pseudarabiensis specimens from Puna are observed in one sample of the uppermost middle part of the Salar del Rincón Formation at Lari Creek which is assigned to the latest Ordovician-earliest Silurian (Fig. 2).

Subfamily Spinachitininae Paris, 1981

\section{Genus Spinachitina Schallreuter, 1963, emend. Paris et al., 1999}

Type species. - Conochitina cervicornis Eisenack, 1931.

\section{Spinachitina cf. S. oulebsiri Paris et al., 2000}

Figure $3 \mathrm{~B}-\mathrm{G}$

Material. - Eleven specimens. Two specimens from sample 9389, one specimen from sample 9396, one specimen from sample 9408, one specimen from sample 9411, one specimen from sample 9412, one specimen from sample 9415, three specimens from sample 9416, and one specimen from sample 9420 .
Table 1. Biometric data for Belonechitina $\mathrm{cf}$. B. pseudarabiensis Butcher, $2009(\mathrm{n}=2)$ from the Salar del Rincón Formation; measured specimens from sample 9420. Measurements are given in micrometres $(\mu \mathrm{m})$.

\begin{tabular}{lccccccccc}
\hline Values & $\mathrm{L}$ & $\mathrm{Ln}$ & $\mathrm{Dp}$ & $\mathrm{dn}$ & $\mathrm{da}$ & $1 \mathrm{~s}$ & $\mathrm{~L} / \mathrm{Dp}$ & $\mathrm{L} / \mathrm{Ln}$ & $\mathrm{Dp} / \mathrm{dn}$ \\
\hline Specimen 1 & 110 & 52 & 75 & 38 & - & 3.3 & 1.47 & 2.12 & 1.97 \\
Specimen 2 & 150 & 68 & 83 & 48 & 52 & 4.4 & 1.81 & 2.21 & 1.73 \\
Mean & 130 & 60 & 79 & 43 & 52 & 3.9 & 1.64 & 2.16 & 1.85 \\
\hline
\end{tabular}

Table 2. Biometric data for Spinachitina cf. S. oulebsiri Paris et al., 2000 $(\mathrm{n}=9)$ from the Salar del Rincón Formation; measured specimens from samples 9389, 9396, 9408, 9411, 9416 and 9420. Measurements in $\mu \mathrm{m}$.

\begin{tabular}{lccccccccc}
\hline Values & L & Ln & Dp & dn & dcoll & 1s & L/Dp & L/Ln & Dp/dn \\
\hline Maximum & 284 & 124 & 197 & 111 & & 13 & 2.27 & 3.74 & 2.41 \\
Mean & 237 & 85 & 139 & 75 & & 10 & 2.04 & 3.19 & 1.76 \\
Minimum & 146 & 39 & 99 & 53 & & 7 & 1.29 & 2.29 & 1.33 \\
\hline
\end{tabular}

Dimensions. - See Tab. 2; Fig. 4A, B.

Discussion. - Because of the usual loss of the apertural end of the vesicle (Fig. 3B1, C1), specimen distortion (Fig. 3D) and damaged ornamentation (Fig. 3C1, C2, D), the Puna specimens are provisionally attributed to Spinachitina oulebsiri Paris et al. 2000. The spines (ca. 12-24), arranged like a crown on the margin, are simple, slender, conical (Fig. 3B2, C2), and robust (Fig. $3 \mathrm{E}-\mathrm{G})$. They are generally longer than spines present on specimens of Spinachitina oulebsiri (Fig. 3E1, E2; Tab. 2). The average length of the spines is $10 \mu \mathrm{m}$, but the spines can be up to $13 \mu \mathrm{m}$ long.

Occurrence. - Spinachitina oulebsiri is considered as the index species for the late to postglacial episodes of the late Hirnantian in northern Gondwana (Paris et al. 2000, Bourahrouh et al. 2004, Webby et al. 2004, Bergström et al . 2009). It was defined in the late Hirnantian (probably the persculptus Zone) of the Upper Member of the M'Kratta Formation (Well N1-2), northeast of Algerian Sahara (Paris et al. 2000) and it is also recorded from western Algerian Sahara and south-eastern Libya (Paris et al. 2000) as well as in northern Chad (Le Hérissé et al. 2013) and in the latest Ordovician to probably the earliest Silurian from south-eastern Libya (Thusu et al. 2013). It is present in the Ordovician-Silurian boundary interval of the Soom Shale Member of the Cedarberg Formation, South Africa (Vandenbroucke et al. 2009). The Spinachitina bulmani (Jansonius, 1964) identified by Elaouad-Debbaj (1984) from the lower Hirnantian (Tanuchitina elongata Zone) of the Bou Ingarf section in the Moroccan Anti-Atlas is included in the synonymy with Spinachitina oulebsiri by Vandenbroucke et al. (2009). Spinachitina oulebsiri is also present in the Hirnantian of the Lower and Upper Members 
of the Second Bani Formation in the central Anti-Atlas of Morocco (Bourahrouh et al. 2004) and the Gorgan Schists and Ghelli Formation of the Alborz Mountains of Iran (Ghavidel-Syooki 2008, 2017; Mahmoudi et al. 2014). In north-western Argentina, incomplete specimens with usually eroded spines are provisionally attributed to Spinachitina oulebsiri. Spinachitina cf. S. oulebsiri is recorded in the Hirnantian glacial related Zapla Formation (de la Puente et al. 2012, de la Puente \& Rubinstein 2013). In Puna, Spinachitina cf. S. oulebsiri is recorded from the lower to the upper-middle part of the Salar del Rincón Formation at the Lari Creek which is assigned to the latest Ordovician-earliest Silurian (Fig. 2).

\section{Spinachitina verniersi Vandenbroucke et al., 2009}

Figure $5 \mathrm{~A}-\mathrm{G}$

2009 Spinachitina verniersi; Vandenbroucke et al., p. 58, pl. 2, figs 1-12 (with complete synonymy).

2011 Spinachitina oulebsiri Paris et al., 2000. - GhavidelSyooki et al., p. 4, fig. 3g-i.

2013 Spinachitina verniersi Vandenbroucke et al., 2009. Le Hérissé et al., fig. 6c, e1, e2, g, h.

2013 Spinachitina verniersi Vandenbroucke et al., 2009. Thusu et al., pl. 6, fig. 3a, b; pl. 7, fig. 2a, b; pl. 8, figs 6a-c, 9a, b, 10a, b.

Material. - Seventy-five specimens. Nine mostly broken specimens from sample 9389, one specimen from sample 9399, three specimens from sample 9404, twenty-two specimens from sample 9407, thirty-two specimens from sample 9408, two specimens from sample 9411, five specimens from sample 9412, and one specimen from sample 9415.

Dimensions. - See Tab. 3; Fig. 4A, B.

Discussion. - Most of the specimens from Puna are of the same size and have the same ornamentation as defined and illustrated in the original description of Spinachitina verniersi (Vandenbroucke et al. 2009). Some specimens from Puna are longer than those from the Spinachitina verniersi type material from South Africa. The Puna specimens have a conical chamber, tapering flanks, and a cylindrical to subcylindrical neck (Fig. 5A1) that is usually missing. Therefore, their total length is uncertain (Fig. 5B). The maximum diameter of the chamber is above the margin (Fig. 5B). The base is flat and usually folded into the chamber (Fig. 5A1, A2, C1, C2, D). This Spinachitina species is characterized by a crown of numerous (24-56) and usually poorly developed conical spines. The double row of spine bases occurs on the margin. The ornament consists of low-relief, linear elements arranged longitudinally that could be the remains of lambda

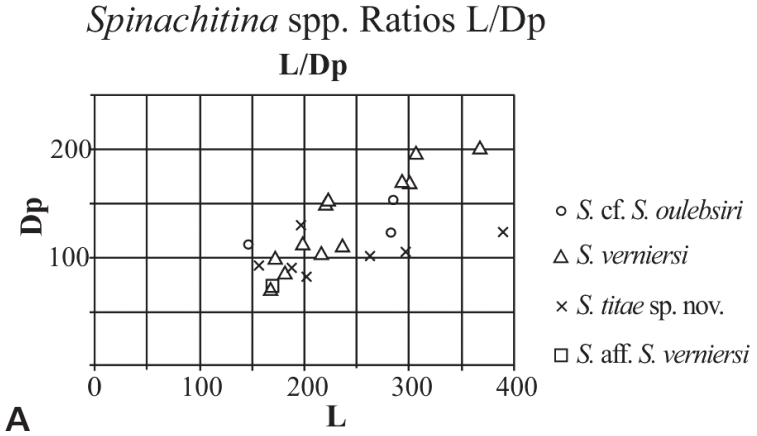

\section{Spinachitina spp. Ratios L/Dp vs. Dp/dn L/Dp vs. Dp/dn}

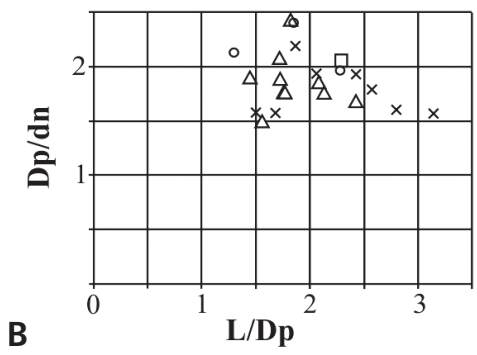

$\circ$ S. cf. S. oulebsiri
$\triangle$ S. verniersi
$\times$ S. titae sp. nov.
$\square$ S. aff. S. verniersi

Figure 4. Biometric comparison of Spinachitina species from the Salar del Rincón Formation, Lari Creek, western Puna. $・$ A - cross-plot of the vesicle length $(\mathrm{L})$ and maximum chamber diameter $(\mathrm{Dp})$. $・ \mathrm{~B}-$ crossplot of the ratios of vesicle length/maximum chamber diameter (L/Dp) and maximum chamber diameter/neck diameter $(\mathrm{Dp} / \mathrm{dn})$.

spines or elongated spine bases (Fig. 5B, C2, F, G). The specimens from Puna are usually broken (Fig. 5B, G), distorted, flattened or three-dimensionally preserved by the infill of sediment (e.g., Fig. 5C1, E1, F). The ornamentation is frequently eroded (Fig. 5D, E2).

Occurrence. - Spinachitina verniersi has been recorded in the Soom Shale Member of the Cedarberg Formation from South Africa, with a latest Hirnantian to probably earliest Rhuddanian age (Vandenbroucke et al. 2009); the M'Kratta Formation (Well N1-2), northeast of Algerian Sahara of a latest Hirnantian age (Paris et al. 2000); the Lower and Upper members of the Second Bani Formation in the central Anti-Atlas of Morocco of the Hirnantian age (Bourahrouh et al. 2004); levels of Late Ordovician-? earliest Silurian age from northern Chad and latest Ordovician to earliest Silurian from south-eastern Libya (Le Hérissé et al. 2013, Thusu et al. 2013); the Ashgill Shales Formation in Northern England (Vandenbroucke et al. 2005); the Cwmere Formation and the Cerig Gwynion Grit facies of the Caban Conglomerate Formation in central Wales (Vandenbroucke et al. 2008). The specimens illustrated as Spinachitina oulebsiri in the latest Hirnantian of the upper Dargaz diamictite of Iran (Ghavidel-Syooki et al. 2011) are considered to belong to Spinachitina verniersi. Spinachitina verniersi from Puna is recorded from the lower to the middle part 
of the Salar del Rincón Formation at Lari Creek which is assigned to the latest Ordovician-earliest Silurian (Fig. 2).

Spinachitina aff. S. verniersi Vandenbroucke et al., 2009 Figure 5H1, H2

Material. - Four specimens. Two specimens from sample 9396, and two specimens from sample 9405.

Dimensions. - See Tab. 4; Fig. 4A, B.

Description and discussion. - These Spinachitina specimens are incomplete (Fig. 5H1). They have a crown of numerous simple and small spines on the margin (Fig. $5 \mathrm{H} 2$ ). The erosion of the spines and the adherent organic material preclude a confident species assignment. The spines are more numerous than those in Spinachitina verniersi Vandenbroucke et al., 2009.

Occurrence. - These specimens are very rare in the lower part of the Salar del Rincón Formation from Lari Creek of Puna that is assigned to the latest Ordovician-earliest Silurian (Fig. 2).

\section{Spinachitina titae sp. nov.}

Figure 6A-H

Types. - Holotype: See Fig. 6A1, A2 (slide repository number 9415, Q39). Paratypes: See Fig. 6B1, B2, D1, D2 (slide repository number 9415, P38/3-L 37/2).

Type horizon and locality. - A level, located at $72 \mathrm{~m}$ above the base of the formation, where sample 9415 was taken. Lower half of the Upper Member of the Salar del Rincón Formation from Puna (Fig. 2). Section along the Quebrada de Lari (Lari Creek), Puna region, Salta Province, northwestern Argentina (Fig. 1).

Material. - Thirty-two frequently broken specimens. A single individual is recorded from sample 9389, two specimens from sample 9407, one specimen from sample 9408 , seventeen specimens from sample 9415, and eleven specimens from sample 9416.
Table 3. Biometric data for Spinachitina verniersi Vandenbroucke et al., $2009(\mathrm{n}=44)$ from the Salar del Rincón Formation; measured specimens from samples 9389, 9399, 9404, 9407, 9408, 9411 and 9412. Measurements in $\mu \mathrm{m}$.

\begin{tabular}{lccccccccc}
\hline Values & $\mathrm{L}$ & $\mathrm{Ln}$ & $\mathrm{Dp}$ & $\mathrm{dn}$ & $\mathrm{dcoll}$ & $\mathrm{ls}$ & $\mathrm{L} / \mathrm{Dp}$ & $\mathrm{L} / \mathrm{Ln}$ & $\mathrm{Dp} / \mathrm{dn}$ \\
\hline Maximum & 367 & 141 & 210 & 100 & & 7 & 2.42 & 3.27 & 2.43 \\
Mean & 254 & 95 & 138 & 71 & 54 & 4 & 1.91 & 3.15 & 1.80 \\
Minimum & 167 & 51 & 69 & 41 & & 3 & 1.47 & 2.08 & 1.50 \\
\hline
\end{tabular}

Table 4. Biometric data for Spinachitina aff. S. verniersi $(\mathrm{n}=44)$ from the Salar del Rincón Formation; measured specimens from samples 9396 and 9405. Measurements in $\mu \mathrm{m}$.

\begin{tabular}{lccccccccc}
\hline Values & L & Ln & Dp & dn & dcoll & 1s & L/Dp & L/Ln & Dp/dn \\
\hline Maximum & - & - & 86 & 50 & - & - & - & - & 2.06 \\
Mean & 169 & 57 & 79 & 43 & - & 4 & 2.28 & 2.96 & 1.89 \\
Minimum & - & - & 74 & 36 & - & - & - & - & 1.72 \\
\hline
\end{tabular}

Etymology. - This species is dedicated to my mother, Graciela "Tita" Salazar, for her valuable support during my studies.

Dimensions. - See Tab. 5; Fig. 4A, B.

Diagnosis. - This species has a conical chamber with tapering flanks, rounded margin and a cylindrical neck. The ornamentation is restricted to the margin. It consists of small weakly differentiated spines surrounded by granules.

Description and discussion. - These Spinachitina specimens have a similar size and shape as Spinachitina verniersi. The ornamentation around the margin consists of granules interspersed with small, weakly differentiated spines and thus distinguishes this species. Both of these elements are restricted to a band on the margin (Fig. $6 \mathrm{~A}-\mathrm{H})$. In a few cases, the granules may extend a short distance on to the base (Fig. 6C2) and the lower part of the chamber (Fig. 6H). Specimens of Spinachitina titae sp. nov. are relatively abundant in the sample 9415, where some longer specimens are observed (Fig.

Figure 5. Latest Ordovician-earliest Silurian chitinozoans from the Salar del Rincón Formation. Scale bar $=50 \mu \mathrm{m} ; 10 \mu \mathrm{m}$ for A2, C2, E2, and H2. • A-G - Spinachitina verniersi Vandenbroucke et al., 2009; A1 - specimen with conical chamber, tapering flanks and a cylindrical to subcylindrical neck, sample 9389; A2 - detail of the margin showing a crown of numerous and poorly developed conical spines, sample 9389; B - broken specimen with the maximum chamber diameter above the margin, sample 9407; C1 - specimen with a crown of numerous poorly developed spines, sample 9407; C2 - detail of the double band of remnant spines on the margin possibly corresponding to the scars of bi-rooted spines, sample 9407; D - specimen with common corroded spines, sample 9389; E1 - three-dimensional specimen infilled with sediment during the deposition, sample 9407; E2 - detail of the base and the margin with corroded spines, sample 9407; F - specimen with numerous less developed spines and a few betterdeveloped spines, sample 9415; G - transitional form between Spinachitina verniersi and Spinachitina titae sp. nov. with coalescence of granules longitudinally forming conical and flat (triangular or longitudinal shape) ornament, incomplete specimen with linear ornament mostly eroded on the margin, sample 9407. • H - Spinachitina aff. S. verniersi, sample 9396; H1 - specimen with a crown of numerous simple, small spines on the margin; $\mathrm{H} 2$ - detail of the eroded ornamentation and adherent organic debris. 
G. Susana de la Puente et al. • Latest Ordovician-earliest Silurian chitinozoans from the Puna region
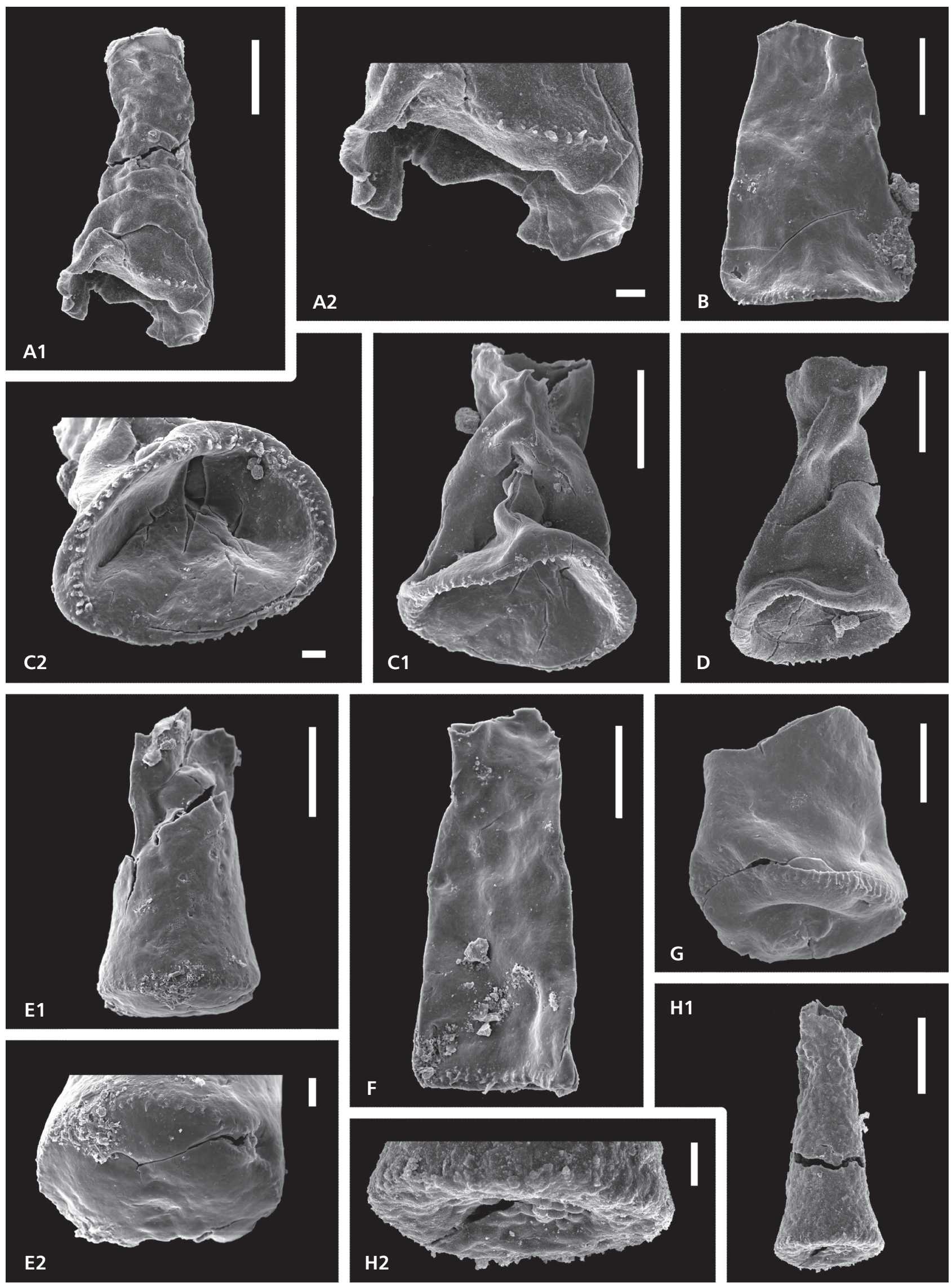
6D1, E). One of these specimens shows a circular scar on its base (Fig. 6D1, D2). Transitional forms between Spinachitina verniersi and Spinachitina titae sp. nov. are recorded. These transitional forms display coalescent spiny remains associated with granules. The spines are more or less longitudinally arranged along the symmetry axis of the chamber and form elongate structures (Fig. 6H1, H2). Spinachitina kourneidaensis (Bouché, 1965) has a different chamber shape and ornamentation type. Spinachitina kourneidaensis illustrated by Paris et al. (2015; pl. 1, fig. 15a, b) has a crown of densely distributed short, but well-individualized, spines. ?Spinachitina verniersi from south-eastern Libya, has no spines and the granules on the margin are not clearly arranged in a single row (see explanation on pl. 6, figs 1, 2 of Thusu et al. 2013).

Occurrence. - Spinachitina titae sp. nov. is rare in the lower part (samples 9389, 9407 and 9408) and common in the middle part (samples 9415 and 9416) of the Upper Member of the Salar del Rincón Formation from Lari Creek of Puna which is assigned to the latest Ordovicianearliest Silurian (Fig. 2).

Family Lagenochitinidae Eisenack, 1931, emend. Paris, 1981

Subfamily Lagenochitininae Paris, 1981

\section{Genus Sphaerochitina Eisenack 1955a, emend. Paris et al., 1999}

Type species. - Lagenochitina sphaerocephala Eisenack, 1932.

\section{Sphaerochitina aff. S. solutidina Paris, 1988}

Figure 7A, B

Material. - Ten specimens. Three specimens from sample 9389, one specimen from sample 9396, one specimen from sample 9405, three specimens from sample 9408, and two specimens from sample 9420 .

Dimensions. - See Tab. 6.
Table 5. Biometric data for Spinachitina titae sp. nov. $(\mathrm{n}=21)$ from the Salar del Rincón Formation; measured specimens from samples 9415 and 9416. Measurements in $\mu \mathrm{m}$.

\begin{tabular}{lccccccccc}
\hline Values & L & Ln & Dp & dn & dcoll & ls & L/Dp & L/Ln & Dp/dn \\
\hline Holotype & 201 & 79 & 83 & 43 & 47 & 7 & 2.42 & 2.54 & 1.93 \\
Paratypes & - & - & $98-100$ & $60-57$ & & -3 & - & - & $1.63-1.75$ \\
Maximum & 389 & 151 & 175 & 103 & 84 & 12 & 3.14 & 3.71 & 2.19 \\
Mean & 246 & 94 & 112 & 63 & 66 & 6 & 2.25 & 3.04 & 1.75 \\
Minimum & 156 & 42 & 83 & 43 & 47 & 3 & 1.50 & 2.18 & 1.57 \\
\hline
\end{tabular}

Table 6. Biometric data for Sphaerochitina aff. S. solutidina Paris, 1988 $(\mathrm{n}=10)$ from the Salar del Rincón Formation; measured specimens from samples 9389, 9396, 9405, 9408 and 9420. Measurements in $\mu \mathrm{m}$.

\begin{tabular}{lccccccccc}
\hline Values & $\mathrm{L}$ & $\mathrm{Lp}$ & $\mathrm{Dp}$ & $\mathrm{dn}$ & $\mathrm{dcoll}$ & $\mathrm{L} / \mathrm{Ln}$ & $\mathrm{L} / \mathrm{Dp}$ & $\mathrm{L} / \mathrm{Lp}$ & $\mathrm{Dp} / \mathrm{dn}$ \\
\hline Maximum & 184 & 97 & 135 & 57 & 71 & 2.55 & 1.96 & 1.94 & 2.45 \\
Mean & 152 & 86 & 87 & 41 & 59 & 2.29 & 1.87 & 1.79 & 2.02 \\
Minimum & 134 & 76 & 67 & 31 & 43 & 2.07 & 1.75 & 1.65 & 1.75 \\
\hline
\end{tabular}

Description and discussion. - The specimens have similar vesicle shapes, dimensions, and ratios as Sphaerochitina solutidina Paris, 1988 but the tuberculate ornamentation on the vesicle (Fig. 7A) is usually absent, probably due to the poor preservation (Fig. 7B). Specimens described by Butcher (2013, pl. 6, figs 1, 2) from south-western Libya are comparable to Sphaerochitina aff. S. solutidina from Puna.

Occurrence. - Sphaerochitina aff. S. solutidina from Puna are observed from the lower to the uppermost middle part of the Salar del Rincón Formation at Lari Creek that is assigned to the latest Ordovician-earliest Silurian (Fig. 2).

Subfamily Cyathochitininae Paris, 1981

\section{Genus Cyathochitina Eisenack 1955a, emend. Paris et al., 1999}

Type species. - Conochitina campanulaeformis Eisenack, 1931.

Figure 6. Latest Ordovician-earliest Silurian chitinozoans from the Salar del Rincón Formation. Scale bar $=50 \mu \mathrm{m}$; $10 \mu \mathrm{m}$ for A2, B2, C2, D2, and H2. - A-H - Spinachitina titae sp. nov. Sample 9415. Slender chitinozoans with a conical chamber, cylindrical neck and small weakly differentiated spines surrounded by granules. The ornamentation is restricted to a zone around the rounded margin; A1 - holotype, specimen with a crown of spines surrounded by granules on the margin; A2 - detail of holotype showing the flattened, invaginated base and the ornamentation on the margin; B1 - paratype, specimen with small weakly differentiated spines surrounded by granules in a zone on the rounded margin; B2 - detail of paratype base showing the ornamentation on the margin, which extends onto the base; $\mathrm{C} 1$ - incomplete specimen with the ornamentation on the margin; $\mathrm{C} 2$ - detail of the base showing the ornamentation on the margin, with the granules extending to the base; D1 - paratype, a long specimen with an invaginated base and the ornamentation in a zone on the margin; D2 - detail of the paratype base showing the basal scar and the ornamentation on the margin; E - a long specimen with eroded ornamentation; F - a short specimen with weakly differentiated spines and granules on the rounded margin; $\mathrm{G}$ - incomplete specimen with eroded spines in a band on the margin; H1 - transitional form between Spinachitina titae sp. nov. and Spinachitina verniersi, broken specimen with the remains of coalescent spines associated with granules on the margin; $\mathrm{H} 2$ - detail of the ornamentation arranged more or less longitudinally along the symmetry axis of the chamber, forming elongate structures. 

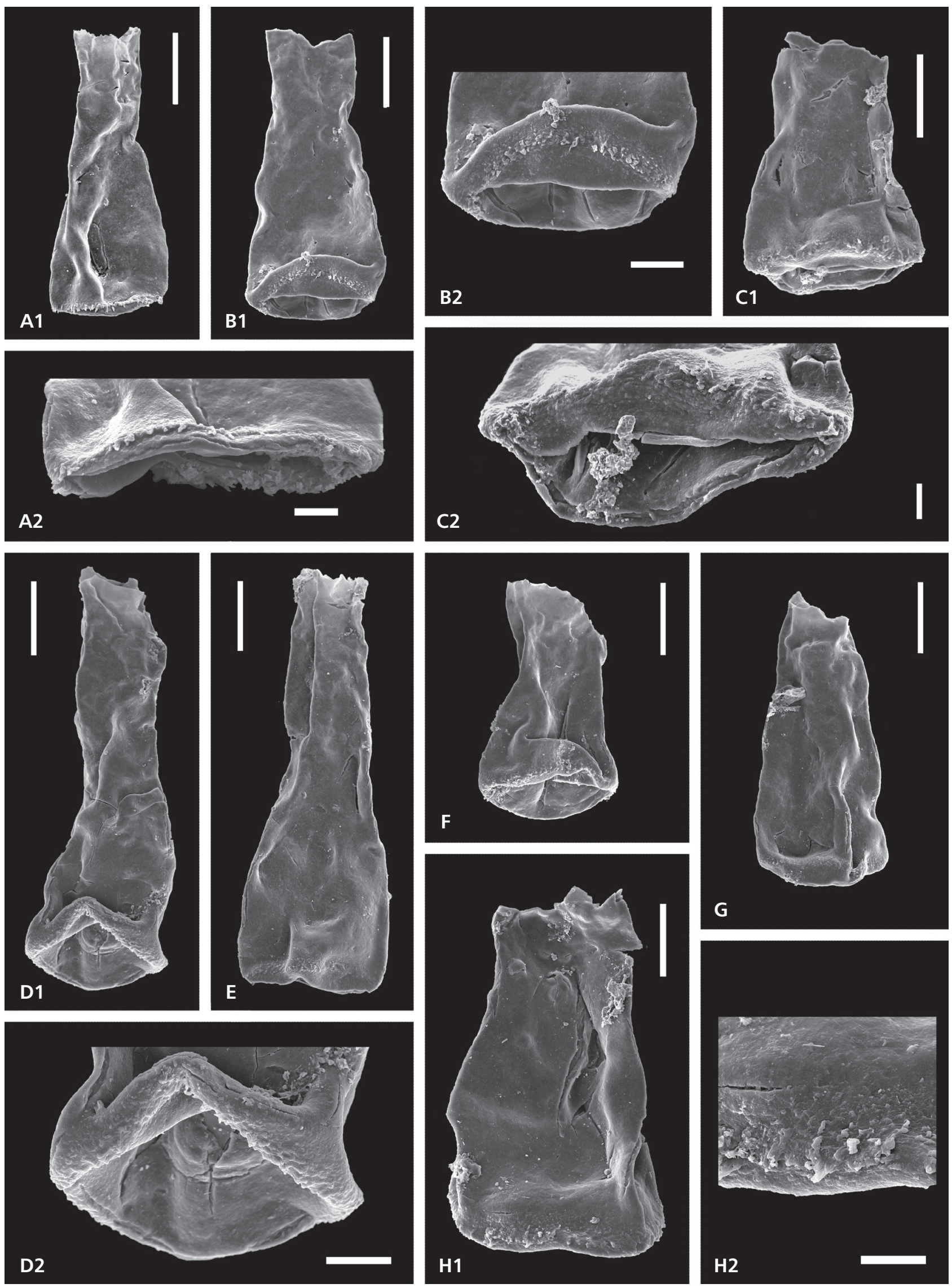


\section{Cyathochitina brussai sp. nov.}

Figure $7 \mathrm{C}-\mathrm{F}$

1989 Cyathochitina spp. - Asselin et al., pl. 1, figs 2, 3.

2000 Cyathochitina campanulaeformis (Eisenack, 1931). Samuelsson \& Verniers, pl. 3, figs 5, 7.

2009 Cyathochitina gr. caputoi da Costa, 1971. Vandenbroucke et al., pl. 4, figs 7, 9, 10.

? 2009 Cyathochitina campanulaeformis (Eisenack, 1931).Butcher, pl. 5, fig. 8.

? 2011 Cyathochitina caputoi da Costa, 1971. - GhavidelSyooki et al., fig. 3a, b.

2013 Cyathochitina e.g. caputoi da Costa, 1971. - Le Hérissé et al., fig. $7 \mathrm{f}$.

? 2013 Cyathochitina caputoi da Costa, 1971. - Thusu et al., pl. 8 , fig. 1 .

Types. - Holotype: See Fig. 7C (slide repository number 9404, K38 base broken). Paratype: See Fig. 7E (slide repository number $9404, \mathrm{~T} 39 / 3$ ).

Type horizon and locality. - Lower half of the Upper Member of the Salar del Rincón Formation from Puna, in a level located at $68 \mathrm{~m}$ above the base of the formation where the sample 9412 was taken (Fig. 2). Section along the Quebrada de Lari (Lari Creek), Puna region, Salta Province, north-western Argentina (Fig. 1).

Material. - Sixty-two specimens. Five specimens from sample 9389, ?one specimen from 9399, seventeen specimens from 9404, four incomplete specimens from 9405 , four specimens from sample 9407, twenty specimens from sample 9408 , five specimens from sample 9411, and six specimens from sample 9412.

Etymology. - The species is named in honour of Edsel Brussa, who studied the graptolites from Argentina, including those from the Puna region.

Dimensions. - See Tab. 7; Fig. 8A, B.
Table 7. Biometric data for Cyathochitina brussai sp. nov. $(\mathrm{n}=19)$ from the Salar del Rincón Formation; measured specimens from samples 9389, 9404, 9407 and 9412. Measurements in $\mu \mathrm{m}$.

\begin{tabular}{lcccccccccc}
\hline Values & $\mathrm{L}$ & $\mathrm{Lp}$ & $\mathrm{Dp}$ & $\mathrm{dn}$ & lcar & tcar & $\mathrm{L} / \mathrm{Dp}$ & $\mathrm{L} / \mathrm{Lp}$ & $\mathrm{Dp} / \mathrm{dn}$ & $\mathrm{Lp} / \mathrm{Dp}$ \\
\hline Holotype & 258 & 157 & 150 & 78 & 11 & 2.6 & 1.72 & 1.64 & 1.92 & 1.05 \\
Paratype & - & 154 & 151 & 61 & 13 & 3.2 & - & - & 2.4 & 1.02 \\
Maximum & 258 & 188 & 179 & 86 & 16 & 4.3 & 1.83 & 1.81 & 2.8 & 1.07 \\
Mean & 212 & 140 & 150 & 64 & 12 & 3.0 & 1.58 & 1.66 & 2.39 & 0.94 \\
Minimum & 180 & 100 & 108 & 47 & 6 & 1.7 & 1.33 & 1.48 & 1.92 & 0.74 \\
\hline
\end{tabular}

Diagnosis. - Small Cyathochitina with a conical thickwalled chamber that is as wide as long, short cylindrical neck, weak flexure, short and thick carina with rounded edge, representing a thickened rim extending from the margin. Vesicle wall is thickest at the flat base.

Description. - This Cyathochitina species has a conical chamber, with a similar diameter and chamber length, and a short cylindrical neck (Fig. 7C, D1). The apertural end and part of the cylindrical neck are frequently absent in the recovered material (Fig. 7E, F). The flanks are slightly convex to straight (Fig. 7C-F). The flexure is moderately distinct (Fig. 7C, D1) to weak (Fig. 7E, F), and the shoulders are poorly developed (Fig. 7C, D1). The wall of the chamber is thick (maximum value $=4.5 \mu \mathrm{m}$ ) (Fig. 7D1, E). The base is flat and has the thickest chamber wall (Fig. 7C, E). Due to the flattening (Fig. 7D2, E), it is frequently folded into the chamber. In a few specimens, it is possible to observe a concentric pattern in the base (Fig. 7F). The maximum diameter is at the rounded basal margin (Fig. 7D1, D2, E, F). The anti-aperturally directed carina is short and thick with a rounded edge, representing an extension of the margin (Fig. 7C, D1, D2, E, F). The surface of the vesicle is smooth (Fig. 7C) or more generally corrugated (Fig. 7D1, E) with longitudinal ribs on the upper chamber and neck (Fig. 7E, F).

Discussion. - The chamber of Cyathochitina brussai sp.

Figure 7. Latest Ordovician-earliest Silurian chitinozoans from the Salar del Rincón Formation. Scale bar $=50 \mu \mathrm{m} ; 10 \mu \mathrm{m}$ for D2, G2, H2, I2, and L2. A, B - Sphaerochitina aff. S. solutidina Paris, 1988; A - specimen with tuberculate ornamentation on the vesicle, sample 9420; B - more common specimens showing no visible ornamentation on the vesicle, probably because of the erosion of the wall, sample 9408. $-\mathrm{C}-\mathrm{F}-$ Cyathochitina brussai sp. nov.; C - holotype, the thick carina extending from the margin, sample 9404; D1 - small Cyathochitina brussai sp. nov. with conical chamber, short cylindrical neck, thick wall and short carina (note the corrugated surface of the vesicle), sample 9412; D2 - detail of the base showing the thick carina with rounded edge, representing a thickened rim extending from the margin, sample 9412; E - paratype (note longitudinal ribs on the upper chamber and neck, and the thick vesicle wall at the flat base), sample 9404; F - note discreet concentric pattern in the base, around the axis of the symmetry, sample 9404. • G-L - Cyathochitina aff. C. brussai (G-I - sample 9412; J-L - sample 9416); G1 - complete vesicle showing the transition between the chamber and neck; G2 - detail of the rounded edges of the thick carina and scar in the centre of the base; H1 - specimen with cylindrical neck and corrugated vesicle surface; H2 - detail of the wall thickness of the flanks and the base; I1 - broken vesicle showing the inconspicuous flexure and straight flanks; I2 - detail of the thickness of the flanks and the base; the interior of the chamber wall is imprinted by crystals of diagenetic pyrite; $\mathrm{J}$ - uncompressed vesicle showing conical chamber, cylindrical neck and the carina in line with the chamber; $\mathrm{K}$ - note the corrugated wall of the vesicle, with vertical ribs on the neck, see also the invaginated base, with a weak concentric lineation around the axis of the symmetry; L1 - note the carina extending from the chamber margin; L2 - detail of the thick carina with a rounded edge. 
G. Susana de la Puente et al. • Latest Ordovician-earliest Silurian chitinozoans from the Puna region
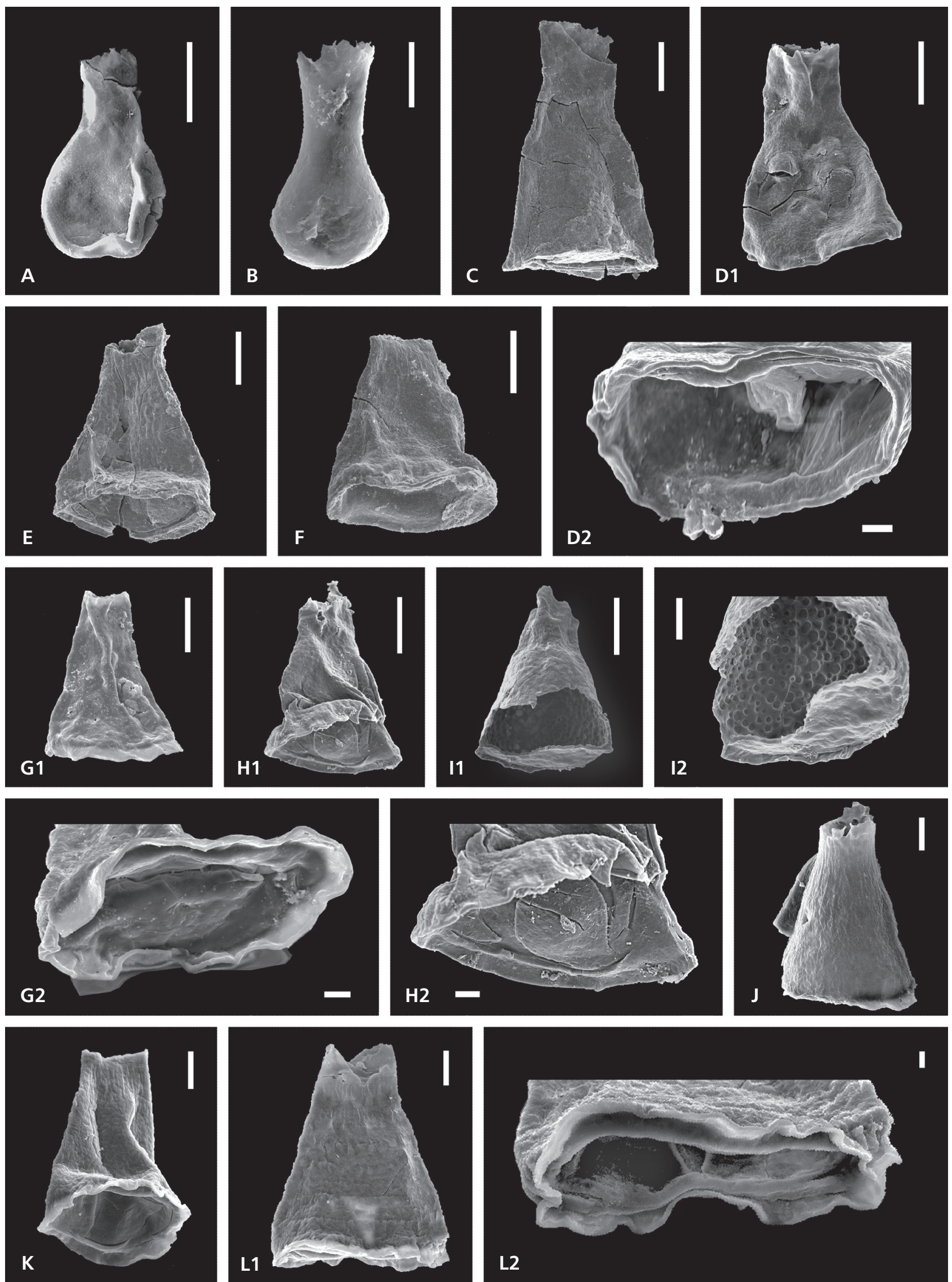


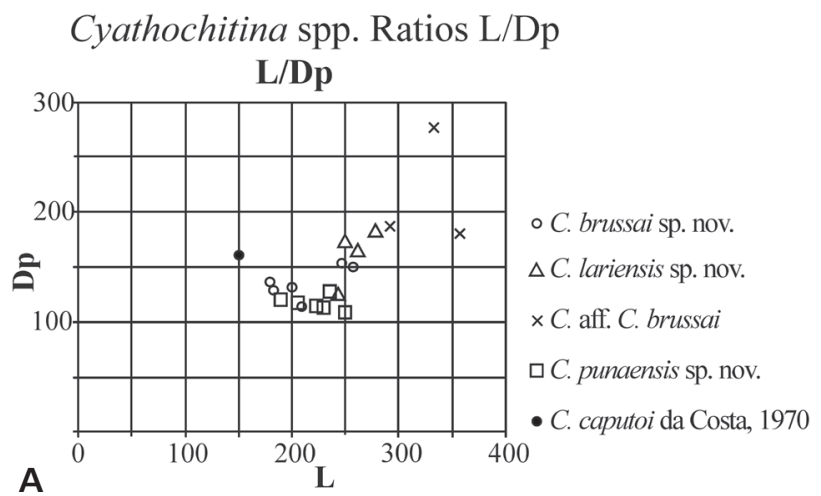

Cyathochitina spp. Ratios Lp/Ln

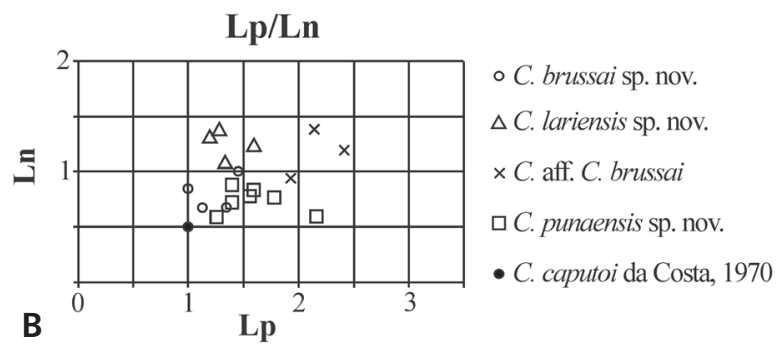

Figure 8. Biometric comparison of Cyathochitina species from the Salar del Rincón Formation, Lari Creek, western Puna, and the holotype of Cyathochitina caputoi da Costa, 1971, for comparison purposes. • A - diagram showing a cross-plot of vesicle length (L) against maximum chamber diameter $(\mathrm{Dp}) . \cdot \mathrm{B}$ - diagram showing the relation between the chamber length (Lp) and oral tube length (Ln).

nov. is less broad than that of the Cyathochitina caputoi type material. Moreover, Cyathochitina brussai sp. nov. has a slightly better developed neck and more differentiated carina than Cyathochitina caputoi, which also differs in having a conspicuous flexure. Cyathochitina campanulaeformis (Eisenack, 1931), a Middle Ordovician common species, has a bell-shaped chamber with conspicuous shoulder. The vesicle is longer $(\mathrm{L}=0.25-0.3 \mathrm{~mm})$ than Cyathochitina brussai sp. nov., which also has a short and thick carina with rounded edge.

Occurrence. - Cyathochitina spp. illustrated by Asselin et al. (1989, pl. 1, figs 2, 3) is from the Rhuddanian of the Clemville Formation, Chaleurs Bay, Canada. In Avalonia, specimens considered here as a synonym of Cyathochitina brussai sp. nov. are from the Hirnantian of the Brutia Formation, Orneau Valley, Brabant Massif, Belgium (Samuelsson \& Verniers 2000, pl. 3, figs 5, 7). In Gondwana, specimens illustrated as Cyathochitina caputoi (Ghavidel-Syooki et al. 2011, fig. 3a, b), associated with Belonechitina pseudarabiensis Butcher, 2009 and Spinachitina oulebsiri, are from the latest Hirnantian of the upper Dargaz diamictite, Zagros Mountains, Iran. Similar specimens have also been reported in the latest
Hirnantian-earliest Rhuddanian from Kufra Basin, southeastern Libya (pl. 8, fig. 1 of Thusu et al. 2013) and probably the Rhuddanian (middle and upper ascensusacuminatus Biozone) of the Mudawwara Shale Formation from Jordan (BG-14 and WS-6 core holes), Middle East (pl. 5, fig. 8 of Butcher 2009). Specimens considered here as belonging to Cyathochitina brussai sp. nov. have been recorded in the Ordovician-Silurian boundary beds of the Soom Shale, South Africa (Vandenbroucke et al. 2009), the latest Hirnantian-? earliest Rhuddanian, associated with Spinachitina verniersi, Spinachitina oulebsiri, and Euconochitina moussegoudaensis Paris in Le Hérissé et al., 2013, of the Moussegouda core from northern Chad (Le Hérissé et al. 2013). Cyathochitina brussai sp. nov. is also recorded in the latest Hirnantian-earliest Rhuddanian from the lowest part (samples NSE 9 to 18) of the Nseirat section from Mauritania, where it is very abundant and occurs with Ramochitina deynouxi sp. nov. and Belonechitina pseudarabiensis (F. Paris, unpublished data). In Puna, Cyathochitina brussai sp. nov. is recorded from the lower to middle part of the Salar del Rincón Formation at Lari Creek that is assigned to the latest Ordovician-earliest Silurian (Fig. 2).

\section{Cyathochitina aff. C. brussai sp. nov.} Figure 7G-L

Material. - Thirty specimens. Fifteen incomplete specimens from sample 9399, three specimens from sample 9412, and 12 specimens from sample 9416.

Dimensions. - See Tab. 8; Fig. 8A, B.

Description. - The Cyathochitina specimens have a conical chamber and a short conical (Fig. 7G1) to cylindrical neck (Fig. 7H1), although the latter is usually missing (Fig. 7J-L1). The flexure is inconspicuous, and the flanks are straight (Fig. 7G1, I1, J, L1). The margin is slightly rounded (Fig. 7L1) and the carina has a rounded edge, is long, thick and an anti-apertural extension of the chamber wall (Fig. 7G1, H1, J, L1, L2). The base is flat, usually invaginated (Fig. 7G2, K, L2), with a weak concentric pattern around the axis of the symmetry (Fig. 7K). The vesicle surface is corrugated with vertical ribs on the neck (Fig. 7J, L1). The specimens from sample 9416 have a slightly wider chamber than those from lower levels.

Discussion. - Cyathochitina aff. C. brussai has a longer carina and a less distinct flexure than Cyathochitina brussai sp. nov.

Occurrence. - This Cyathochitina species has been recorded from the lower and middle part of the Salar del 
Rincón Formation at Lari Creek of Puna which is assigned to the latest Ordovician-earliest Silurian (Fig. 2).

\section{Cyathochitina lariensis sp. nov.}

Figure 9A-H

$$
\begin{aligned}
& \text { ?2005 Cyathochitina cf. C. campanulaeformis (Eisenack, } \\
& \text { 1931). - Grahn, fig. 3e. }
\end{aligned}
$$

Types. - Holotype: See Fig. 9A1, A2 (slide repository number 9389, J41/3-4). Paratype: See Fig. 9H (slide repository number $9389,038 / 3$ ).

Type horizon and locality. - Basal part of the Upper Member of the Salar del Rincón Formation from Puna, in a level located at $40 \mathrm{~m}$ above the base of the formation where the sample 9389 was taken (Fig. 2). Section along the Quebrada de Lari (Lari Creek), Puna region, Salta Province, north-western Argentina (Fig. 1).

Material. - Fifty-three specimens. Fourteen mostly incomplete specimens from sample 9389, nine specimens from sample 9404, seven specimens from sample 9407, four specimens from sample 9408, nine specimens from sample 9411, and ten specimens from sample 9412.

Etymology. - From Lari, the name of the creek from where specimens were recovered.

Dimensions. - See Tab. 9; Fig. 8A, B.

Diagnosis. - Cyathochitina with a campanulate chamber and a conspicuous flexure. The neck is almost as long as the chamber. The carina is long (up to $22 \mu \mathrm{m}$ ) and thick, with a rounded and edge. It is an extension of the rounded margin that gently flairs anti-aperturally.

Description. - These large specimens are usually incomplete (commonly only the chamber is recovered) and poorly preserved; therefore, a complete morphological analysis is challenging. The species is characterized by a campanulate chamber (Fig. 9A-G). This character is altered in flattened individuals (Fig. 9H). The flexure is marked, and the flanks are convex near the junction with the neck forming a shoulder, straight at the mid length of the chamber and becoming concave in the lower part of the chamber (Fig. 9A1, B, E1, F1, G1). The neck is cylindrical and frequently incomplete (apertural end missing). It is almost the same length as the chamber (Figs 8B, 9A1; Tab. 9). The vesicle wall is thick (maximum value $=4.7 \mu \mathrm{m})($ Fig. 9B, C, G1, G2). The basal margin is sharp (Fig. 9A2, F1, G1). The rather long carina (Tab. 9) extends anti-aperturally from the margin; it is thick with a rounded edge (Fig. 9A1, A2, D-F2, H). The vesicle
Table 8. Biometric data for Cyathochitina aff. C. brussai $(\mathrm{n}=12)$ from the Salar del Rincón Formation; measured specimens from samples 9399 and 9416. Measurements in $\mu \mathrm{m}$.

\begin{tabular}{lcccccccccc}
\hline Values & $\mathrm{L}$ & $\mathrm{Lp}$ & $\mathrm{Dp}$ & $\mathrm{dn}$ & lcar & tcar & $\mathrm{L} / \mathrm{Dp}$ & $\mathrm{L} / \mathrm{Lp}$ & $\mathrm{Dp} / \mathrm{dn}$ & $\mathrm{Lp} / \mathrm{Dp}$ \\
\hline Maximum & 356 & 297 & 332 & 131 & 20 & 6.5 & 1.98 & 1.51 & 2.63 & 1.32 \\
Mean & 332 & 214 & 208 & 99 & 16 & 4.5 & 1.60 & 1.50 & 2.19 & 1.10 \\
Minimum & 291 & 164 & 128 & 68 & 13 & 2 & 1.21 & 1.50 & 1.73 & 0.80 \\
\hline
\end{tabular}

Table 9. Biometric data for Cyathochitina lariensis sp. nov. $(\mathrm{n}=21)$ from the Salar del Rincón Formation; measured specimens from samples 9389, 9404, 9411 and 9412. Measurements in $\mu \mathrm{m}$.

\begin{tabular}{lcccccccccc}
\hline Values & $\mathrm{L}$ & $\mathrm{Lp}$ & $\mathrm{Dp}$ & $\mathrm{dn}$ & lcar & tcar & $\mathrm{L} / \mathrm{Dp}$ & $\mathrm{L} / \mathrm{Lp}$ & $\mathrm{Dp} / \mathrm{dn}$ & $\mathrm{Lp} / \mathrm{Dp}$ \\
\hline Holotype & 262 & 130 & 164 & 67 & 17 & 3.2 & 1.60 & 2.02 & 2.45 & 0.79 \\
Paratype & 250 & 123 & 174 & 69 & 15 & 2.4 & 1.44 & 2.03 & 2.52 & 0.71 \\
Maximum & 278 & 245 & 333 & 117 & 22 & 5.0 & 1.94 & 2.03 & 3.03 & 1.10 \\
Mean & 259 & 145 & 195 & 78 & 18 & 3.3 & 1.64 & 1.89 & 2.43 & 0.78 \\
Minimum & 244 & 67 & 107 & 46 & 14 & 2.2 & 1.44 & 1.76 & 2.15 & 0.47 \\
\hline
\end{tabular}

surface is commonly wrinkled (Fig. 9A1, A2), but may be smooth. Weakly transverse or longitudinal ridges (Fig. 9G1), or a combination, may be present (Fig. 9C, D, E1, $\mathrm{F} 1, \mathrm{H})$. The base is flat with a basal scar surrounded by ribs (Fig. 9C-G2).

Discussion. - Cyathochitina lariensis sp. nov. is distinguished from Cyathochitina kuckersiana (Eisenack, 1934) by the campanulate chamber and its thick carina. Based on the mean $\mathrm{Dp} / \mathrm{L}$ ratios (Fig. 8A) it is possible to differentiate all Puna Cyathochitina species. Cyathochitina lariensis sp. nov. has a greater maximum diameter when compared to Cyathochitina brussai sp. nov. and Cyathochitina punaensis sp. nov. that have similar total lengths. Regarding Cyathochitina campanulaeformis (Eisenack, 1931), the dimensions of the specimens from Puna are similar to the holotype but greater than those usually reported for this species elsewhere (see Paris 1981, Butcher 2009). Cyathochitina lariensis sp. nov. has a larger L/Dp ratio (Tab. 9) than Cyathochitina campanulaeformis (Eisenack, 1931) [L/Dp $=(1.3-1.6) / 1]$. The flanks of Cyathochitina lariensis sp. nov. are straighter. The carina is not membranous. Cyathochitina lariensis sp. nov. differs from Cyathochitina jenkinsi Neville, 1974 because the latter has a membranous carina, and a longer and narrow neck that slightly tapers toward the aperture.

Occurrence. - Cyathochitina cf. C. campanulaeformis illustrated by Grahn (2005) is from the lower Silurian Vargas Peña Formation of Mina Cué, eastern Paraguay. Cyathochitina lariensis sp. nov. from Puna is recorded from the lower to middle part of the Salar del Rincón Formation at Lari Creek that is assigned to the latest 
Ordovician-earliest Silurian (Fig. 2). Lower Llandovery Cyathochitina specimens identified as Cyathochitina campanulaeformis in several papers (e.g. Achab 1981) might belong to Cyathochitina lariensis sp. nov. However, they are not included in the synonymy because of the lack of information on their morphological variability.

\section{Cyathochitina punaensis sp. nov.} Figure 10A-J

2013 Cyathochitina jenkinsi Neville, 1974. - de la Puente in de la Puente \& Rubinstein, pl. 2, fig. 10.

Types. - Holotype: See Fig. 10A1, A2 (slide repository number 9420, M38/1). Paratype: See Fig. 10D1, D2 (slide repository number 9420, M36/3).

Type horizon and locality. - Upper half of the Upper Member of the Salar del Rincón Formation from Puna, in a level located at $92 \mathrm{~m}$ above the base of the formation where the sample 9420 was taken (Fig. 2). Section along the Quebrada de Lari (Lari Creek), Puna region, Salta Province, north-western Argentina (Fig. 1).

Material. - Twenty-six specimens. Twenty-three mostly complete and flattened specimens from sample 9420, and three specimens from sample 9423 .

Etymology. - From Puna, the region from where the specimens have been recovered.

Dimensions. - See Tab. 10; Fig. 8A, B.

Diagnosis. - Slender Cyathochitina with an elongate chamber, a short cylindrical neck and a short, thick carina. The gently tapering chamber walls are thick, with a corrugated surface.

Description. - Cyathochitina with a truncated elongate ovoid chamber $($ mean $\mathrm{Lp} / \mathrm{Dp}=1.22)($ Fig. $10 \mathrm{~A}-\mathrm{J})$. The
Table 10. Biometric data for Cyathochitina punaensis sp. nov. $(\mathrm{n}=16)$ from the Salar del Rincón Formation; measured specimens from sample 9420. Measurements in $\mu \mathrm{m}$.

\begin{tabular}{lcccccccccc}
\hline Values & $\mathrm{L}$ & $\mathrm{Lp}$ & $\mathrm{Dp}$ & $\mathrm{dn}$ & lcar & tcar & $\mathrm{L} / \mathrm{Dp}$ & $\mathrm{L} / \mathrm{Lp}$ & $\mathrm{Dp} / \mathrm{dn}$ & $\mathrm{Lp} / \mathrm{Dp}$ \\
\hline Holotype & 189 & 130 & 121 & 70 & 10 & 2.8 & 1.56 & 1.45 & 1.73 & 1.07 \\
Paratype & 249 & 177 & 110 & 68 & 12 & 4 & 2.26 & 1.41 & 1.62 & 1.61 \\
Maximum & 271 & 215 & 149 & 80 & 13 & 4.0 & 2.26 & 1.62 & 2.16 & 1.61 \\
Mean & 231 & 153 & 127 & 68 & 11 & 3.2 & 1.91 & 1.47 & 1.85 & 1.22 \\
Minimum & 189 & 111 & 108 & 57 & 8 & 2.2 & 1.56 & 1.26 & 1.62 & 0.91 \\
\hline
\end{tabular}

neck is short (Fig. 8B) and cylindrical, ending in a short collarette (Fig. 10A1, C, D1). The specimens show a variable vesicle length while the range of the chamber diameter is more restricted. Depending on differential flattening of the vesicle (neck and upper part of the chamber flatten more than the margin) the general outline is variable (Figs $8 \mathrm{~B} ; 10 \mathrm{~A} 1, \mathrm{D} 1)$. The flexure is marked (Fig. 10A1, C, E) to inconspicuous (Fig. 10D1, F) and the weak shoulders may be accentuated due to the effects of flattening. The flanks are convex (Fig. 10C, D1, F, G1) to straight (Fig. 10A1, H). The maximum diameter of the chamber is located close to the margin (Fig. 10B1, D1, H). The basal margin is sharp (Fig. 10F, H) but may look like rounded due to a distortion resulting from the flattening (Fig. 10E, H). All specimens have a short, thick carina with a blunt edge (Fig. 10A2, B2, D2, G2), and is directed anti-aperturally (Fig. 10D1). The base is flat, usually folded into the chamber (Fig. 10A2, B2). It has concentric ornamentation surrounding the central scar (Fig. 10I1, I2, $\mathrm{J} 2$ ). The surface of the vesicle is corrugated, in some cases with a linear pattern (Fig. 10D1, H, J1, J2). The vesicle wall is thick (maximum value $=4.3 \mu \mathrm{m}$ ).

Discussion. - Cyathochitina punaensis has a shorter neck, and different chamber outline, flanks, and carina than the specimens assigned herein to Cyathochitina lariensis sp. nov. Cyathochitina punaensis is distinguished from other Cyathochitina species from Puna by the smaller

Figure 9. Latest Ordovician-earliest Silurian chitinozoans from the Salar del Rincón Formation. Scale bar $=50 \mu \mathrm{m} ; 10 \mu \mathrm{m}$ for A2, E2, F2, and G2. • A-H - Cyathochitina lariensis sp. nov. with a large campanulate chamber, long neck (L/Lp mean $=1.89)$, and long and thick carina, with a rounded and thick edge extending from the sharp margin; A1 - holotype, typical vesicle shape, sample 9389; A2 - detail of the wrinkled chamber surface and of the thick carina, sample 9389; B - campanulate chamber and thick wall (see the wall thickness in the broken central part), sample 9404; C - basal margin and flat base, with a subtle scar and circular ribs; see the thickness of the wall in the broken lower part, sample 9404; D - same characters present on the specimen Fig. 9C, see the basal scar, the distinct carina and the wrinkled surface of the vesicle, probably resulting from transverse and longitudinal ribs, sample 9412; E1 - campanulate chamber and longitudinal ribbing on the neck; see the carina, with a rounded and thick edge extending from the margin, sample 9411; E2 - detail of the flat base, with a scar, subtle circular ribs, and the thick rounded edge carina, sample 9411; F1 - campanulate chamber, with convex (toward the neck), straight and parallel (at the middle length of the chamber) and concave (toward the base) flanks, sample 9411; F2 - detail of the flat base with a marked scar and circular rings, sample 9411; G1 - campanulate chamber, with sharp margin, wrinkled surface and transverse ribbing, sample 9407; G2 - detail of the base with a marked scar and circular rings, sample 9407; H - paratype, flattened specimen with longitudinal ribbing on the neck; note the thickening of the carina, with a rounded, thick edge extending from the sharp margin, sample 9389 . I - Tasmanites tzadiaensis Le Hérissé et al., 2013. Specimen with characteristic solid verrucae. Sample 9408. 

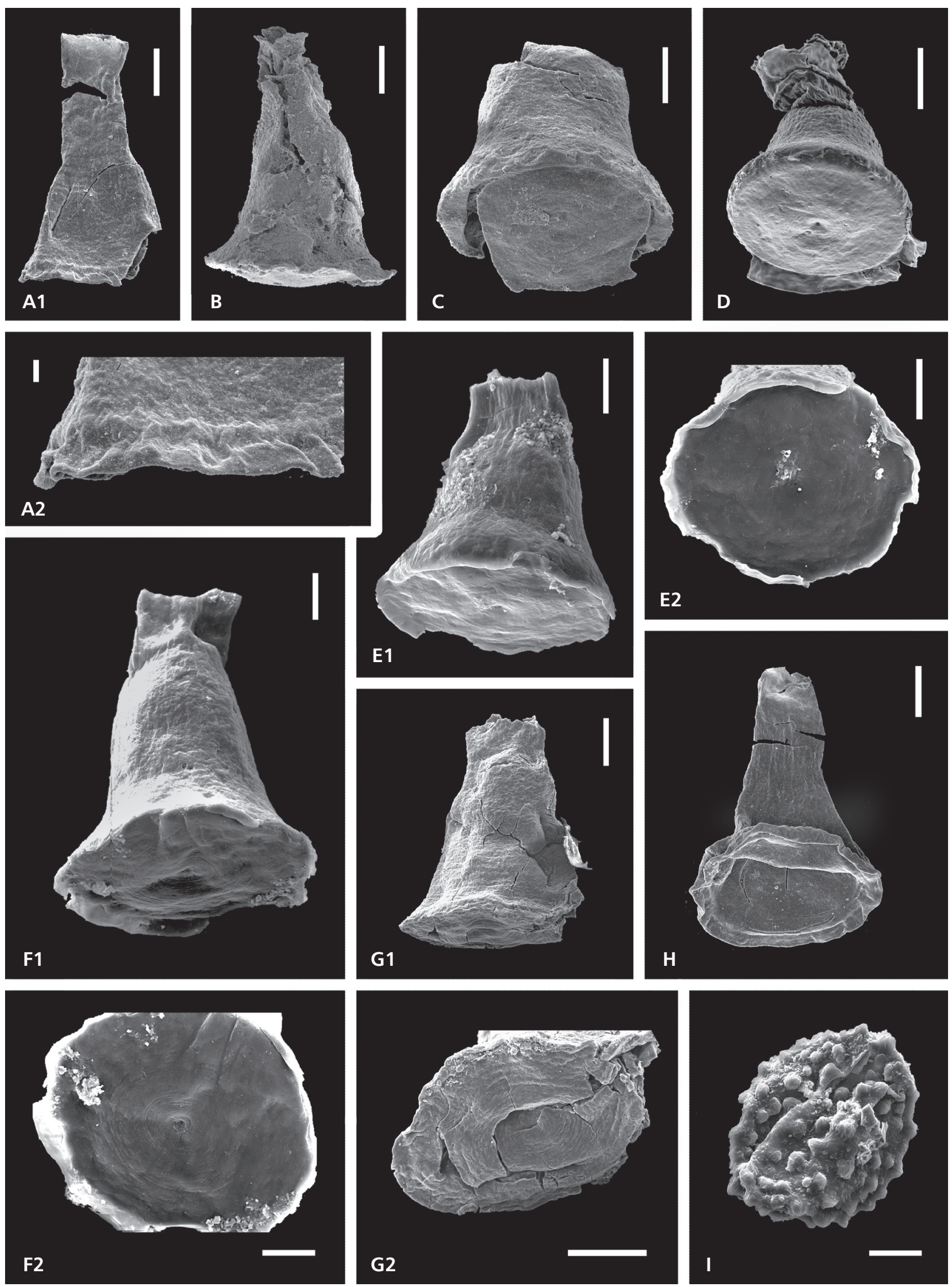
maximum diameter of its chamber (Fig. 8A) and by its elongate chamber (Fig. 8B), with convex to straight flanks. The carina is represented by a thickening of the margin instead of a membranous structure. Such a blunt carina was reported by Paris et al. (2012) in specimens assigned to Cyathochitina caputoi.

Occurrence. - Cyathochitina punaensis sp. nov. was first identified as Cyathochitina jenkinsi Neville, 1974 by de la Puente (in de la Puente \& Rubinstein 2013). It is recorded in the upper part of the Salar del Rincón Formation at Lari Creek from Puna that is assigned to the latest Ordovicianearliest Silurian (Fig. 2).

\section{Cyathochitina cf. C. caputoi da Costa, 1971}

Figure 11A, B

Material. - Nine incomplete and flattened specimens from sample 9423.

Dimensions. - See Tab. 11, Fig. 12.

Description and discussion. - These specimens are close to Cyathochitina caputoi described from Brazil (da Costa 1971), with a conical chamber (flanks opened around $30-40^{\circ}$ from the neck) but the neck is missing, and they have a greater chamber size than given for the holotype of Cyathochitina caputoi da Costa, 1971 (Figs $11 \mathrm{~A} 1, \mathrm{~B} 1 ; 12)$. The short and thick carina corresponds to a thickening of the margin (Fig. 11A2, B2). The vesicle surface is wrinkled with longitudinal ribs on the neck (Fig. 11A1, B1). These Cyathochitina specimens from Puna are similar to Cyathochitina caputoi from the Rhuddanian of North Central Saudi Arabia illustrated by Paris et al. (2015, pl. 6, figs 1-3, 5). They have a similar chamber and carina morphologies although they are also larger than the specimens illustrated as Cyathochitina caputoi from the latest Hirnantian-earliest Rhuddanian from south-eastern Libya by Thusu et al. (2013, pl. 11, fig. 21), and from the Aeronian-early Telychian of south Brazil by Grahn et al. (2000, pl. 2, fig. 3) and Grahn (2005, fig. 3d).
Table 11. Biometric data for Cyathochitina cf. C. caputoi da Costa, $1971(\mathrm{n}=6)$ from the Salar del Rincón Formation; measured specimens from sample 9423. Measurements in $\mu \mathrm{m}$.

\begin{tabular}{lcccccccccc}
\hline Values & L & Lp & Dp & dn & lcar & tcar & L/Dp & L/Lp & Dp/dn & Lp/Dp \\
\hline Maximum & - & 210 & 248 & 124 & 16 & 8.0 & - & - & 2.34 & 0.90 \\
Mean & - & 181 & 218 & 101 & 13 & 5.7 & - & - & 2.16 & 0.81 \\
Minimum & - & 152 & 193 & 88 & 7 & 3.5 & - & - & 1.97 & 0.77 \\
\hline
\end{tabular}

Occurrence. - The type material of Cyathochitina caputoi was from the Llandovery of Igarapé da Rainha (Pará, Brazil) (da Costa 1971). Cyathochitina caputoi from North Central Saudi Arabia are from the earliest Rhuddanian basal Qusaiba Member of the Qalibah Formation in the Qusaiba-1 core hole (Paris et al. 2015). The specimens from south-eastern Libya are from the latest Hirnantianearliest Rhuddanian of the Kufra Basin in the UN-REMSA well (Thusu et al. 2013). Cyathochitina caputoi from south Brazil are from the Aeronian-early Telychian of the Paraná Basin in RD-116 well and from the Vargas Peña Fm. in Minas Cué (Grahn et al. 2000, Grahn 2005). In Argentina, Cyathochitina gr. caputoi is associated with Telychian chitinozoans from the lower half of the Lipeón Formation in the Caspalá area of Cordillera Oriental (de la Puente 2009, Rubinstein et al. 2016). Cyathochitina cf. C. caputoi from Puna is observed in the uppermost shaley interval of the Salar del Rincón Formation at Lari Creek which is assigned to the latest Ordovician-earliest Silurian (Fig. 2).

Subfamily Ancyrochitininae Paris, 1981

Genus Ancyrochitina Eisenack, 1955b

Type species. - Conochitina ancyrea Eisenack, 1931.

\section{Ancyrochitina cf. A. prima Bouché, 1965}

Figure 11C1, C2

Material. - Ten specimens from sample 9415.

Dimensions. - See Tab. 12.

Figure 10. Latest Ordovician-earliest Silurian chitinozoans from the Salar del Rincón Formation. Scale bar $=50 \mu \mathrm{m} ; 10 \mu \mathrm{m}$ for A2, B2, D2, G2, I2, and J2. A-J - Cyathochitina punaensis sp. nov. Slender Cyathochitina specimens with truncated ovoid elongate chambers, corrugated surface and a thick wall, short cylindrical necks, and an anti-aperturally directed short, thick carina. All specimens from sample 9420; A1 - holotype, specimen with a short total length compared with the specimen in Fig. 10D1; A2 - detail of the invaginated base caused by flattening (note the blunt edge of the short and thick carina); B1 - specimen with broken neck and distinctly corrugated vesicle surface; B2 - detail of the carina, as a thickened extension of the margin; C - specimen with marked flexure; D1 - paratype, slender specimen with a very slightly flaring collarette; D2 - detail of the short and thick carina, parallel to the axis of symmetry, and the corrugated surface of the wall, see the thickening of the wall in the broken base; E - specimen with a basal margin that looks rounded from flattening, the neck is short and cylindrical; F - specimen with inconspicuous flexure and sharp basal margin; G1 - specimen with convex flanks; G2 - detail of the short, thick carina and the wall thickness; $\mathrm{H}$ - specimen with straight flanks and corrugated chamber wall simulating transverse lineations; I1 - specimen with a simulated rounded basal margin due to the distortion by the flattening; I2 - detail of the inwardly collapsed base, with concentric rims surrounding a central scar; J1 - broken specimen, with a corrugated chamber surface simulating longitudinal lineations; J2 - detail of the inwardly collapsed base showing concentric rings; note the thickening of the wall in the broken base. 

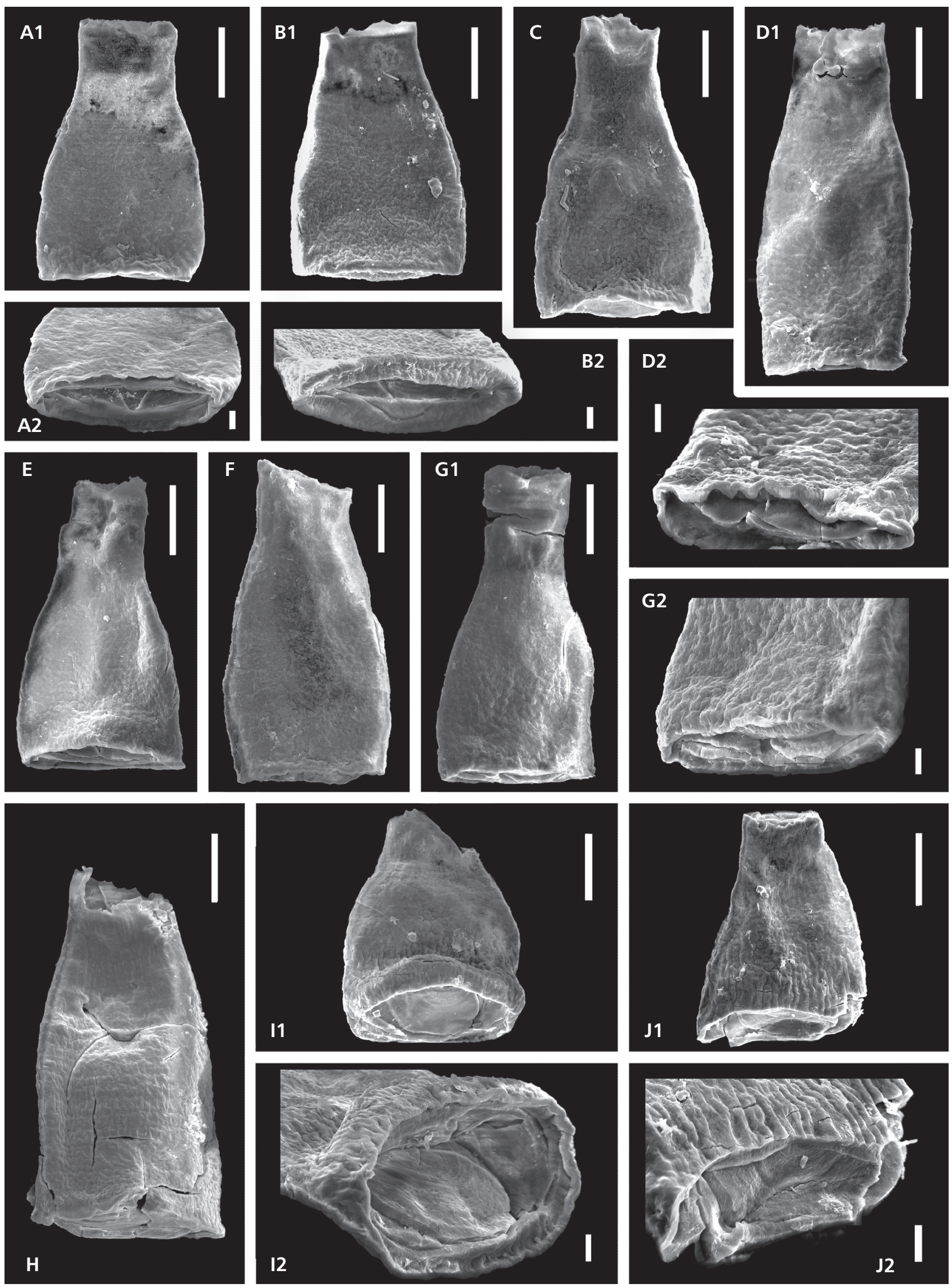
Description and discussion. - These specimens have the same chamber shape, neck, collarette, and dimensions as Ancyrochitina prima Bouché, 1965 but the long, simple, and slender processes $(n=6-8)$ are frequently broken (Fig. 11C1). Thus, the identification is provisional. The vesicle surface is smooth or has remnants of granules, probably eroded (Fig. 11C2).

Occurrence. - Ancyrochitina prima was described in the Upper Ordovician of the Djado Basin (Kourneida 1-Kr. 1 core hole), Niger (Bouché 1965). The specimens from Puna occur in the middle part of the Salar del Rincón Formation at Lari Creek which is assigned to the latest Ordovician-earliest Silurian (Fig. 2).

\section{Ancyrochitina sp.}

Figure 11D1, D2

Material.-Twenty-threespecimens. Twenty-one specimens from sample 9396, and two specimens from sample 9412.

Dimensions. - See Tab. 13.

Description and discussion. - The chamber is conical and the base convex to flat (Fig. 11D1). The flanks are straight, the flexure inconspicuous and the shoulders absent. The neck is cylindrical and gently flaring toward the aperture. The collarette is usually missing. These Ancyrochitina specimens have a diameter similar to that of Ancyrochitina cf. A. prima Bouché, 1965 from Puna but they are slightly shorter. The main difference is the branching processes $(n=6-8)$. Although incomplete, they are clearly branched (Fig. 11D2), with the first branching at a short distance from the margin. Their distal parts seem to be sub-parallel to the longitudinal axis (Fig. 11D1). These specimens
Table 12. Biometric data for Ancyrochitina cf. A. prima Bouché, 1965 $(\mathrm{n}=6)$ from the Salar del Rincón Formation; measured specimens from sample 9415. Measurements in $\mu \mathrm{m}$.

\begin{tabular}{lccccccccc}
\hline Values & $\mathrm{L}$ & $\mathrm{Lp}$ & $\mathrm{Dp}$ & $\mathrm{dn}$ & $\mathrm{dcoll}$ & $\mathrm{L} / \mathrm{Ln}$ & $\mathrm{L} / \mathrm{Dp}$ & $\mathrm{L} / \mathrm{Lp}$ & $\mathrm{Dp} / \mathrm{dn}$ \\
\hline Maximum & 149 & 95 & 88 & 38 & 45 & 2.76 & 1.88 & 1.93 & 2.55 \\
Mean & 134 & 79 & 78 & 33 & 40 & 2.45 & 1.72 & 1.71 & 2.36 \\
Minimum & 115 & 71 & 68 & 29 & 33 & 2.07 & 1.51 & 1.57 & 2.05 \\
\hline
\end{tabular}

Table 13. Biometric data for Ancyrochitina sp. $(\mathrm{n}=14)$ from the Salar del Rincón Formation; measured specimens from samples 9396 and 9412. Measurements in $\mu \mathrm{m}$.

\begin{tabular}{lccccccccc}
\hline Values & L & Lp & Dp & dn & dcoll & L/Ln & L/Dp & L/Lp & Dp/dn \\
\hline Maximum & 144 & 87 & 86 & 41 & 42 & 3.03 & 1.96 & 2.06 & 3.00 \\
Mean & 127 & 69 & 78 & 33 & 36 & 2.36 & 1.65 & 1.78 & 2.40 \\
Minimum & 115 & 54 & 67 & 27 & 31 & 1.95 & 1.37 & 1.49 & 1.87 \\
\hline
\end{tabular}

also have some randomly distributed simple spines $(1 \mathrm{~s}=$ $2.9 \mu \mathrm{m}$ ) visible on the neck (Fig. 11D1).

Occurrence. - The specimens from Puna are recorded in the lower part of the Salar del Rincón Formation at Lari Creek that is assigned to the latest Ordovician-earliest Silurian (Fig. 2).

Subfamily Angochitininae Paris, 1981

Genus Angochitina Eisenack, 1931

Type species. - Angochitina echinata Eisenack, 1931.

Angochitina sp.

Figure 11E

Figure 11. Latest Ordovician-earliest Silurian chitinozoans from the Salar del Rincón Formation. Scale bar $=50 \mu \mathrm{m} ; 10 \mu \mathrm{m}$ for C2, and D2. • A, B - Cyathochitina cf. C. caputoi da Costa, 1971. Specimens with a conical chambers and missing necks. Sample 9423 ; A1 - specimen with a short and thick carina; A2 - detail of the flat and smooth base, note the thick carina with rounded edge; B1 - specimen with the carina as a thickening of the margin, wrinkled surface wall with longitudinal ribs on the neck; B2 - detail of the carina. $-\mathrm{C}-$ Ancyrochitina cf. A. prima Bouché, 1965; $\mathrm{C} 1$ - specimen with broken processes $(\mathrm{n}=c a .6-8)$, sample $9415 ; \mathrm{C} 2$ - detail of the base; see the remnant granules on the base surface, sample 9415 . $\bullet$ D - Ancyrochitina sp.; D1 - specimen with branched processes and spiny ornamentation on the surface of the neck, sample 9396; D2 - detail of the first branching at a short distance from the chamber, sample 9396. E - Angochitina sp. Specimen with a dense ornamentation of simple spines longer on the chamber than on the neck. Sample 9420. $\cdot \mathrm{F}-\mathrm{L}$ - Ramochitina deynouxi sp. nov. Small Ramochitina specimens with an ornamentation of simple, bi- or multirooted spines arranged in longitudinal rows (F-G - sample 9396; H-L - sample 9420); F - small specimen with cylindrical neck, marked flexure and inconspicuous shoulder, the ornamentation is mostly eroded but it is possible to observe a row of simple spines on the chamber and small simple spines on the neck; G - specimen with an ovoid chamber and inconspicuous shoulder, the ornamentation is mostly eroded but it is possible to observe rows of simple longer hair-like spines, probably connected by their bases, on the chamber; $\mathrm{H}$ - holotype, specimen with long lambda, bi- and multirooted spines, connected by their bases forming longitudinal rows on the chamber and the neck; I - specimen with eroded ornamentation with remnant of rows on the chamber; $\mathrm{J}$ - specimen with long and thick simple and lambda spines, on the chamber and the neck; $\mathrm{K}$ - specimen with a dense ornamentation of long hair-like spines, simple or lambda bases, arranged in longitudinal rows on the chamber and short simple spines on the neck; L - specimen with an ovoid chamber and a dense ornamentation of long hair-like spines, with common bi-rooted or lambda shape connected by their bases forming longitudinal rows on the chamber, short simple eroded spines and small rounded cones on the neck. $\bullet$ M - ?Ramochitina deynouxi sp. nov. Specimen with long and dense spinous ornamentation covering the chamber and the long neck, not in apparent rows. Sample 9420. • N-Q - Ancyrochitininae; N - a probable Ancyrochitina sp., with broken processes, sample 9423; O-Q - small chitinozoans with broken processes. Probably Plectochitina spp., with broken processes $(\mathrm{n}=c a$. 8$)$ and blunt spines or granules on the vesicle, sample 9420. 
G. Susana de la Puente et al. • Latest Ordovician-earliest Silurian chitinozoans from the Puna region
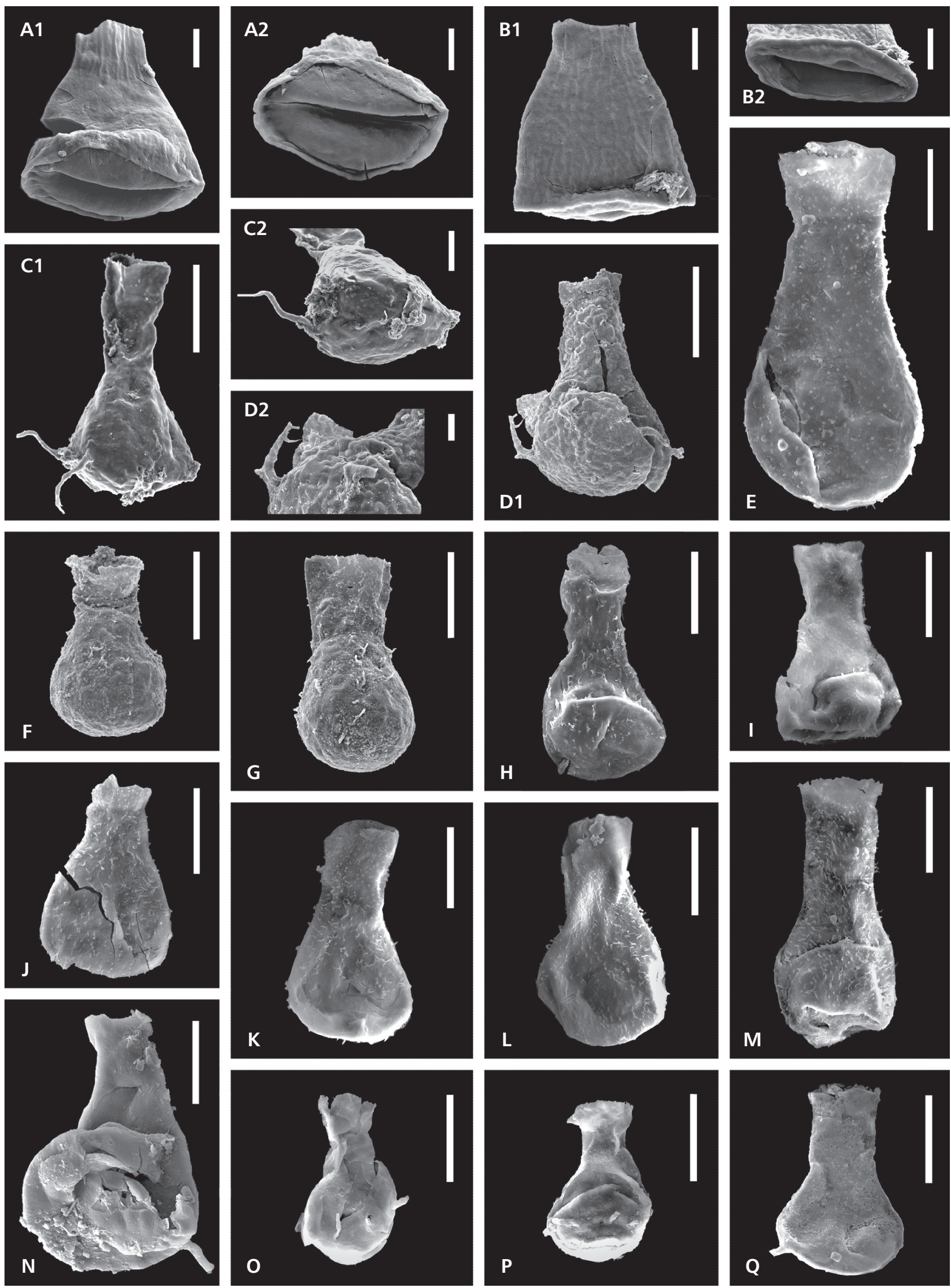
Material. - Four specimens. One specimen from sample 9412, two distorted specimens from sample 9415, and one specimen from sample 9420 .

Dimensions. - See Tab. 14.

Description and discussion. - Chitinozoans with an ovoid chamber (Fig. 11E) that display spinose ornamentation. The flexure is marked and the shoulder inconspicuous. The short subcylindrical neck, which is ended with a slightly flaring collarette, is around one third of the total length of the vesicle. The surface of the neck and the chamber is covered by a dense ornamentation of simple spines. They are longer but likely broken on the chamber $(<4 \mu \mathrm{m})$.

Occurrence. - Specimens from Puna are from the middle and upper part of the Salar del Rincón Formation at Lari Creek that is assigned to the latest Ordovician-earliest Silurian (Fig. 2).

\section{Genus Ramochitina Sommer \& van Boekel, 1964, emend. Paris et al., 1999}

Type species. - Ramochitina ramosi Sommer \& van Boekel, 1964.

\section{Ramochitina deynouxi sp. nov.}

Figure 11F-L

Holotype. - See Fig. 11H (slide repository number 9420, O42/4).

Type horizon and locality. - Upper half of the Upper Member of the Salar del Rincón Formation, in a level located at $92 \mathrm{~m}$ above the base of the formation where the sample 9420 was taken (Fig. 2). Section along the Quebrada de Lari (Lari Creek), Puna region, Salta Province, north-western Argentina (Fig. 1).

Material. - Seventy-four specimens. Five specimens from sample 9396, one specimen from sample 9407, one specimen from sample 9411, four specimens from sample 9412, two specimens from sample 9415 , fourty-two specimens from sample 9420, and nineteen specimens from sample 9423.

Etymology. - The species name is dedicated to the late Max Deynoux, the geologist who has initiated the biostratigraphical studies of the Nseirat Section of Mauritania, where Florentin Paris first recovered this species.

Dimensions. - See Tab. 15.

Diagnosis. - An Angochitininae species that has an ovoid chamber and a cylindrical neck, which is approximately $1 / 3$ of the total length. The spines and crests, better developed on the chamber flanks, are arranged in longitudinal rows of connected spines, sometimes bi- and multirooted.

Description and discussion. - These specimens have an ovoid chamber, a cylindrical neck, which is around $1 / 3$ of the total length and $1 / 2$ of the total width of the vesicle (Tab. 15). The flexure is marked, and the shoulder is inconspicuous (Fig. 11F-L). The ornamentation on the vesicle surface includes bi- and multirooted spines (Fig. 11F-H, K, L), frequently eroded in the recovered specimens from Puna (Fig. 11I). It also commonly includes simple, conical and longer hair-like spines (Fig. $11 \mathrm{~J}, \mathrm{~L}$ ), where the subtle arrangement in longitudinal rows is difficult to image. It is probably because of the presence of the remains of the broken multirooted spines, which make the ornamentation anomalously denser (Fig. $11 \mathrm{~J})$. In this case, the species is very similar to Belonechitina pseudarabiensis Butcher, 2009, which has a similar size although the neck is not distinct and the ornamentation is different (denser randomly distributed simple spines). The spines are shorter on the neck and limited to smaller rounded cones on the apertural end (Fig. 11J-L). Ramochitina deynouxi sp. nov. differs from Ramochitina ruhnuensis (Nestor, 1982) in its shorter neck (L/ln $=2$ in $R$. ruhnuensis). Ramochitina ruhnuensis also has longer spines and can include distally branched spines (Nestor 1982, 1994). Angochitina murzukensis Paris et al., 2012 has similar shape and proportions as well, but it is smaller, and the slightly shorter spiny ornamentation is not arranged in longitudinal rows.

Occurrence. - Ramochitina deynouxi sp. nov. from Puna is recorded in the lower (but not lowermost), middle and

Table 14. Biometric data for Angochitina sp. $(\mathrm{n}=4)$ from the Salar del Rincón Formation; measured specimens from samples 9412, 9415 and 9420. Measurements in $\mu \mathrm{m}$.

\begin{tabular}{lccccccccc}
\hline Values & $\mathrm{L}$ & $\mathrm{Ln}$ & $\mathrm{Dp}$ & $\mathrm{dn}$ & $\mathrm{dcoll}$ & $\mathrm{L} / \mathrm{Ln}$ & $\mathrm{L} / \mathrm{Dp}$ & $\mathrm{L} / \mathrm{Lp}$ & $\mathrm{Dp} / \mathrm{dn}$ \\
\hline Maximum & 138 & 48 & 71 & 35 & 43 & 4.22 & 1.95 & 1.56 & 2.38 \\
Mean & 125 & 40 & 65 & 31 & 40 & 3.26 & 1.91 & 1.47 & 2.11 \\
Minimum & 114 & 27 & 62 & 26 & 36 & 2.79 & 1.84 & 1.31 & 1.88 \\
\hline
\end{tabular}

Table 15. Biometric data for Ramochitina deynouxi sp. nov. $(\mathrm{n}=47)$ from the Salar del Rincón Formation; measured specimens from samples 9396, 9420 and 9423. Measurements in $\mu \mathrm{m}$.

\begin{tabular}{lccccccccc}
\hline Values & L & Ln & Dp & dn & dcoll & ls & L/Dp & L/Lp & Dp/dn \\
\hline Holotype & 134 & 65 & 75 & 34 & 41 & 6.2 & 1.79 & 1.94 & 2.21 \\
Maximum & 207 & 83 & 131 & 63 & 62 & 12.0 & 2.16 & 1.97 & 2.65 \\
Mean & 140 & 54 & 84 & 42 & 44 & 5.6 & 1.68 & 1.62 & 2.03 \\
Minimum & 99 & 35 & 62 & 28 & 34 & 2.1 & 1.27 & 1.26 & 1.54 \\
\hline
\end{tabular}




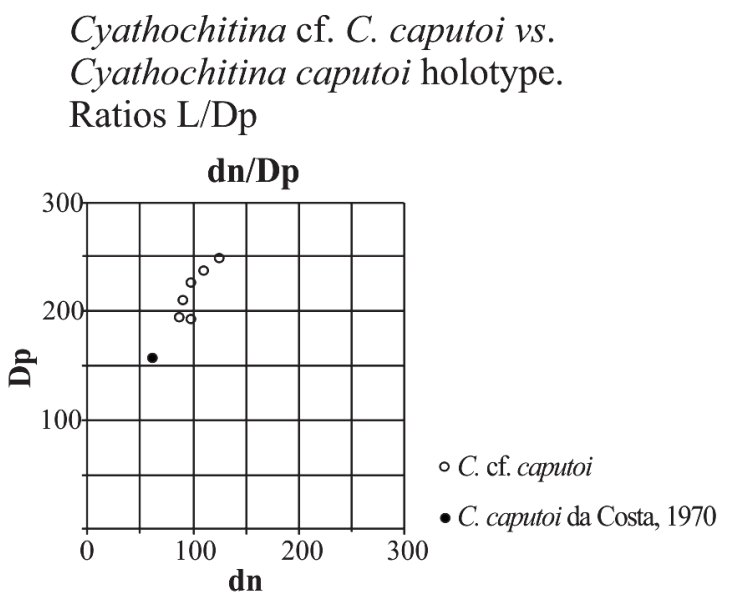

Figure 12. Biometric comparison of Cyathochitina $\mathrm{cf}$. C. caputoi from the Salar del Rincón Formation, Lari Creek, western Puna, and the holotype of Cyathochitina caputoi da Costa, 1971, showing the relation between the neck diameter ( $\mathrm{dn}$ ) and the maximum chamber diameter (Dp).

upper part of the Salar del Rincón Formation at Lari Creek, which is assigned to the latest Ordovician-earliest Silurian (Fig. 2). This species has been previously recovered in the lowermost part of Nseirat section of Mauritania, samples NSE 8-11, which has been assigned to the persculptus Biozone (Paris et al. 1998, Underwood et al. 1998).

\section{Conclusions}

Latest Hirnantian-earliest Rhuddanian chitinozoans from the western Argentine Puna allow the correlation of these western Gondwana deposits with postglacial deposits from other northern Gondwana regions, such as North Africa and Arabian Peninsula. The chitinozoan assemblages from the Upper Member of the Salar del Rincón Formation include species, such as, Spinachitina cf. S. oulebsiri and Spinachitina verniersi that characterize the OrdovicianSilurian boundary interval in northern Gondwana regions. Several new species, Spinachitina titae sp. nov., Ramochitina deynouxi sp. nov., Cyathochitina brussai sp. nov., Cyathochitina lariensis sp. nov. and Cyathochitina punaensis sp. nov., are present and described from the studied section. Ramochitina deynouxi sp. nov. and Cyathochitina brussai sp. nov. occur, but were not described, from the Ordovician-Silurian boundary section in northern Gondwana as well (F. Paris unpublished data). The occurrences with cosmopolitan, but common northern Gondwanan, cryptospores, such as Segestrespora laevigata, Imperfectotriletes patinatus and Laevolancis chibrikovae, from postglacial deposits confirm this age (Le Hérissé et al. 2013, Wellman et al. 2015, Ghavidel-Syooki 2017). Additionally, the presence of Tasmanites tzadiaensis also supports a latest Hirnantian-earliest Rhuddanian postglacial stage and northern Gondwana affinities, being this its first record outside of the northeast of Africa (Le Hérissé et al. 2013, Thusu et al. 2013). A nearshore depositional setting is suggested by the terrestrial input. In spite of the lack of direct evidence of glacially related deposits in this part of the basin, the Upper Member of the Salar del Rincón Formation could include the postglacial stage of the late Hirnantian glaciation according to chitinozoans and stratigraphically significant associated palynomorphs.

The stratigraphic relationship between the Upper and the Lower members of the Salar del Rincón Formation should be re-evaluated since their erosive contact involves a change to a different depositional environment and possibly represents an important hiatus. The Upper Member of the Salar del Rincón Formation is tentatively correlated with the basal part of the Lipeón Formation in the eastern part of the basin that record the flooding surface occurring after the late Hirnantian glaciation (e.g. Astini \& Marengo 2006, de la Puente et al. 2012, Benedetto et al. 2015). However, the chitinozoan assemblage from Puna is slightly older. The Upper Ordovician-lower Silurian glacially related deposits from the Central Andean Basin suggest the existence of diachronism, possibly controlled by palaeotopography. The presence of different depocentres in the basin, such as in Puna and those in the Cordillera Oriental and Sierras Subandinas (e.g. Astini \& Marengo 2006, de la Puente et al. 2012, Benedetto et al. 2015, Rubinstein et al. 2016), allows various locally preserved records of the latest glacial and postglacial events as described for other contemporaneous northern Gondwana basins (e.g. Paris et al. 1998, 2015; Lüning et al. 2000; Ghavidel-Syooki et al. 2011; Le Hérissé et al. 2013).

\section{Acknowledgements}

Financial support for this study was provided by the FONCYT (PICT 2010-2784; PICT 2016-0558) and SECyT-ECOS Project A05U01 (Scientific Cooperation Programme between Argentina and France). This work is a contribution to the International Geoscience Programme (IGCP) Project 653 - The onset of the Great Ordovician Biodiversification Event. We especially thank Merrell Miller (Tulsa, USA) for exhaustive review of the manuscript, linguistic improvement of the English content, and valuable technical suggestions prior to submission. We also thank reviewers A. Butcher, J. Verniers and anonymous, as well as editor O. Fatka for valuable comments that improve the work.

\section{References}

Aceñolaza, F.G., Benedetto, J.L. \& Salfity, J.A. 1972. E1 Neopaleozoico de la Puna Argentina: su fauna y relación con áreas vecinas. Academia Brasileira de Ciencias, Anales 44 (Suplemento), 5-20. 
Аснав, A. 1981. Biostratigraphie par les chitinozoaires de l'Ordovicien Supérieur Silurien Inférieur de l'Île d'Anticosti, résultats préliminaries, 143-157. In Lespérance, P.J. (ed.) Field meeting, Anticosti-Gaspé, Québec, II: Stratigraphy and Palaeontology. Subcomission on Silurian Stratigraphy. Ordovician-Silurian Boundary Working Group, Montreal.

Asselin, E., Achab, A. \& Bourque, P.A. 1989. Chitinozoaires du Silurien inférieur dans la région de la baie des Chaleurs en Gaspésie, Québec, Canada. Canadian Journal of Earth Sciences 26, 2435-2449. DOI 10.1139/e89-208

Astini, R.A. 2008. Sedimentación, facies, discordancias y evolución paleoambiental durante el Cambro-Ordovícico, 50-73. In Coira, B. \& Zappettini, E.O. (eds) Geología y Recursos Naturales de la Provincia de Jujuy, XVII Congreso Geológico Argentino, Jujuy, Relatorio.

Astini, R.A. \& Marengo, L. 2006. Paleoambientes y estratigrafía secuencial de depósitos marinos marginales del Ordovícico de la sierra de Zapla (Sierras Subandinas, noroeste argentino) y su relación con la Cuenca Andina Central. Revista Geológica de Chile 33, 247-276.

DOI 10.4067/S0716-02082006000200003

Benedetto, J.L. \& SÁnchez, T.M. 1990. Fauna y edad del estratotipo de la Formación Salar del Rincón (Eopaleozoico, Puna Argentina). Ameghiniana 27, 317-326.

Benedetto, J.L., Halpern, K., De la Puente, G.S. \& Monaldi, C.R. 2015. An in situ shelly fauna from the lower Paleozoic Zapla diamictite of northwestern Argentina: Implications for the age of glacial events across Gondwana. Journal of South American Earth Sciences 64, 166-182.

DOI 10.1016/j.jsames.2015.10.004

Bergström, S.M., Chen, X., Gutiérrez-Marco, J.C. \& Dronov, A. 2009. The new chronostratigraphic classification of the Ordovician System and its relations to major regional series and stages and to $\delta^{13} \mathrm{C}$ chemostratigraphy. Lethaia 42, 97-107. DOI 10.1111/j.1502-3931.2008.00136.x

Bouché, P.M. 1965. Chitinozoaires du Silurien s.l. du Djado (Sahara nigérien). Revue de Micropaléontologie 8, 151-164.

Bourahrouh, A. 2002. Chitinozoaires et palynomorphes de l'Ordovicien supérieur nord-gondwanien; impact de la glaciation ashgilienne. 300 pp. Ph.D. thesis, Rennes University, Rennes, France.

Bourahrouh, A., Paris, F. \& Elaouad-Debbaj, Z. 2004. Biostratigraphy, biodiversity and palaeoenvironments of the chitinozoans and associated palynomorphs from the Upper Ordovician of the Central Anti-Atlas, Morocco. Review of Palaeobotany and Palynology 130, 17-40.

DOI 10.1016/j.revpalbo.2004.01.002

Burgess, N.D. 1991. Silurian cryptospores and miospores from the type Llandovery area, south-west Wales. Palaeontology 34, 575-599.

Butcher, A. 2009. Early Llandovery chitinozoans from Jordan. Palaeontology 52, 593-629.

DOI 10.1111/j.1475-4983.2009.00862.x

Butcher, A. 2013. Chitinozoans from the middle Rhuddanian (lower Llandovery, Silurian) 'hot' shale in the E1-NC174 core, Murzuq Basin, SW Libya. Review of Palaeobotany and Palynology 198, 62-91. DOI 10.1016/j.revpalbo.2012.11.009
Butcher, A., Mikulic, D. \& Kluessendorf, J. 2010. Late Ordovician-Early Silurian chitinozoans from northeastern and western Illinois, USA. Review of Palaeobotany and Palynology 159, 81-93.

DOI 10.1016/j.revpalbo.2009.11.002

CostA, N.M. DA 1971. Quitinozoários silurianos do Igarapé da Rainha, Estado do Para. Estado do Pará. Departamento Nacional da Produção Mineral. Divisão de Geologia e Mineralogia Boletim 255, 1-101.

De la Puente, G.S. 2009. Quitinozoos del Ordovícico de la Cuenca Andina Central (noroeste argentino) y su aplicación a la bioestratigrafía, paleobiogeografía y paleoambientes. 245 pp. Ph.D. thesis, Facultad de Ciencias Exactas, Físicas y Naturales, Universidad Nacional de Córdoba, Córdoba, Argentina.

De la Puente, G.S. \& Rubinstein, C.V. 2013. Ordovician chitinozoans and marine phytoplankton of the Central Andean Basin, northwestern Argentina: A biostratigraphic and paleobiogeographic approach. Review of Palaeobotany and Palynology 198, 14-26. DOI 10.1016/j.revpalbo.2012.03.007

de la Puente, G.S., Astini, R.A., Rubinstein, C.V. \& Oviedo, N. 2012. Latest Ordovician-earliest Silurian chitinozoans from northwestern Argentina, Western Gondwana. 45 th Annual Meeting of AASP - The Palynological Society and Meeting of the CIMP - Commission Internationale de la Microflore du Paléozoïque Subcommissions, Lexington, Program \& Abstracts, 17-19.

Donato, E.O. \& Vergani, G. 1985. Geología del Devónico y Neopaleozoico de la zona del cerro Rincón, Provincia de Salta, Argentina. $4^{\circ}$ Congreso Geológico Chileno, Actas 1 , 262-283.

Dorning, K.J. \& Harding, J.L. 1998. Environmental distribution of the Ordovician-Recent terrestrial to freshwater acritarchs and algae, including Concentricystes, Moyeria and Pediastrum. CIMP Symposium and Workshops, Pisa, Abstracts 37.

EISENACK, A. 1931. Neue Mikrofossilien des baltischen Silurs 1. Palaeontologische Zeitschrift 13, 74-118. DOI 10.1007/BF03043326

EISENACK, A. 1932. Neue Mikrofossilien des baltischen Silurs 2. Palaeontologische Zeitschrift 14, 257-277. DOI 10.1007/BF03042096

EISENACK, A. 1934. Neue Mikrofossilien des baltischen Silurs III und Neue Mikrofossilien des böhemischen Silurs I. Palaeontologische Zeitschrift 16, 52-76. DOI 10.1007/BF03041667

EIsEnACK, A. 1955a. Neue Chitinozoen aus dem Silur des Baltikums und dem Devon der Eifel. Seckenbergiana Lethaea 36, 311-319.

EISENACK, A. 1955b. Chitinozoen, Hystrichospharen und andere Mikrofossilien aus dem Beyrichia-Kalke. Senckenbergiana Lethaea 36, 157-188.

EISENACK, A. 1958. Mikrofossilien aus dem Ordovizium des Baltikums. Senckenbergiana Lethaea 131, 133-152.

EISENACK, A. 1959. Neotypen baltischer Silur-Chitinozoen und neue Arten. Neues Jahrbuch für Geologie und Paläontologie, Abhandlungen 108, 1-20. 
Eisenack, A. 1972. Beitrage zur Chitinozoen Forschung. Palaeontographica, Abteilung A 140, 117-130.

Elaouad-Debbaj, Z. 1984. Chitinozoaires ashgilliens de l'AntiAtlas (Maroc). Géobios 17(1), 45-68. DOI 10.1016/S0016-6995(84)80005-4

Ghavidel-Syooki, M. 2008. Palynostratigraphy and Palaeogeography of the Upper Ordovician Gorgan Schists (Southeastern Caspian Sea), Eastern Alborz Mountain Ranges, Northern Iran. Comunicações Geológicas 95, 123-155.

Ghavidel-Syooki, M. 2017. Cryptospores and trilete spore assemblages from the Late Ordovician (Katian-Hirnatian) Gelli Formation, Alborz Mountain Range, Northeastern Iran: palaeophytogeographic and palaeoclimatic implications. Review of Palaeobotany and Palynology 244, 217-240. DOI 10.1016/j.revpalbo.2017.05.010

Ghavidel-Syooki, M., Álvaro, J.J., Popov, L., Ghobadi Pour, M., Ehsani, M.H. \& SuYArKova, A. 2011. Stratigraphic evidence for the Hirnantian (latest Ordovician) glaciation in the Zagros Mountains, Iran. Palaeogeography, Palaeoclimatology, Palaeoecology 307, 1-16. DOI 10.1016/j.palaeo.2011.04.011

Grahn, Y. 2005. Early Silurian chitinozoans in the Apucarana Sub-basin (Paraná Basin), South Brazil, and their biostratigraphic provenance. Revista Brasileira de Paleontologia 8(3), 209-214. DOI 10.4072/rbp.2005.3.05

Grahn, Y., Pereira, E. \& Bergamaschi, S. 2000. Silurian and Lower Devonian chitinozoan biostratigraphy of the Paraná Basin in Brazil and Paraguay. Palynology 24, 147-176. DOI 10.2113/0240147

JANSONIUS, J. 1964. Morphology and classification of some Chitinozoa. Bulletin of Canadian Petroleum Geologists 12, 901-918.

Le Hérissé, A., Paris, F. \& Steemans, P. 2013. Late Ordovicianearliest Silurian palynomorphs from northern Chad and correlation with contemporaneous deposits of southeastern Libya. Bulletin of Geosciences, 88(3), 483-504. DOI 10.3140/bull.geosci.1383

Lüning, S., Craig, J., Loydell, D.K., Štorch, P. \& Fitches, B. 2000. Lower Silurian 'hot shales' in North Africa and Arabia: regional distribution and depositional model. Earth-Science Reviews 49, 121-200. DOI 10.1016/S0012-8252(99)00060-4

Mahmoudi, M., Saburi, J., Alimohammadian, H. \& Majidifard, M.R. 2014. The first cryptospore assemblages of Late Ordovician in Iran, Ghelli Formation, eastern Alborz. Geopersia 4, 125-140.

Miller, M.A. \& Eames, L.E. 1982. Palynomorphs from the Silurian Medina Group (Lower Llandovery) of the Niagara Gorge, Lewiston, New York, U.S.A. Palynology 6, 221-254. DOI 10.1080/01916122.1982.9989243

Monaldi, C.R. \& Boso, M.A. 1987. Dalmanitina (Dalmanitina) subandina nov. sp. (Trilobita) en la Formación Zapla del norte argentino. $4^{\circ}$ Congreso Latinoamericano de Paleontología, Actas 1, 149-157.

Moya, M.C., Malanca, S., Hongn, F.D. \& Bahlburg, H. 1993. El Tremadociano temprano de la Puna occidental argentina. $12^{\circ}$ Congreso Geológico Argentino \& $2^{\circ}$ Congreso de Exploración de Hidrocarburos, Actas 2, 20-30.

Nestor, V. 1980. New chitinozoan species from the lower
Llandovery of Estonia. Proceedings of the Estonian Academy of Sciences, Geology 29, 98-107.

Nestor, V. 1982. New chitinozoans of the genera AncyroGotlando- and Sphaerochitina from the Wenlockian of Estonia. Proceedings of the Estonian Academy of Sciences, Geology 31(4), 146-151. [in Russian with English summary]

Nestor, V. 1994. Early Silurian chitinozoans of Estonia and North Latvia. Academia 4, 1-163.

DOI 10.1016/0034-6667(74)90018-9

Neville, R.S.W. 1974. Ordovician chitinozoa from Western Newfoundland. Review of Palaeobotany and Palynology 18, 187-221.

PARIs, F. 1981. Les chitinozoaires dans le Paléozoïque du sudouest de 1'Europe (cadre géologique, étude systématique, biostratigraphie). Mémoire de la Société géologique et minéralogique de Bretagne, Rennes 26, 1-496.

PARIS, F. 1988. New Chitinozoans from the Late OrdovicianLate Devonian of northeast Libya, 73-87. In El Arnauti, A., Thusu, B. \& Owens, B. (eds) Subsurface Palynostratigraphy of Northeast Libya. Garyounis University, Benghazi.

Paris, F., Bourahrouh, A. \& Le Hérissé, A. 2000. The effects of the final stages of the Late Ordovician glaciation on marine palynomorphs (chitinozoans, acritarchs, leiospheres) in well N1-2 (NE Algerian Sahara). Review of Palaeobotany and Palynology 113, 87-104. DOI 10.1016/S0034-6667(00)00054-3

Paris, F., Deynoux, M. \& Ghienne, J.F. 1998. Découverte de chitinozoaires à la limite Ordovicien-Silurien en Mauritanie; implications paléogéographiques. Comptes rendus de l'Académie des Sciences Paris 326, 499-504. DOI 10.1016/S1251-8050(98)80077-3

Paris, F., Grahn, Y., Nestor, V. \& Lakova, I. 1999. A revised chitinozoan classification. Journal of Paleontology 73, 549-570. DOI 10.1017/S0022336000032388

Paris, F., Thusu, B., Rasul, S., Meinhold, G., Strogen, D., Howard, J.P., Abutarruma, Y., Elgadry, M. \& Whitham, A.G. 2012. Palynological and palynofacies analysis of early Silurian shales from borehole CDEG-2a in Dor el Gussa, eastern Murzuq Basin, Libya. Review of Palaeobotany and Palynology 174, 1-26. DOI 10.1016/j.revpalbo.2012.02.002

Paris, F., Verniers, J., Miller, M.A., Al-Hajri, S., Melvin, J. \& Wellman, C.H. 2015. Late Ordovician-earliest Silurian chitinozoans from the Qusaiba-1 core hole (North Central Saudi Arabia) and their relation to the Hirnantian glaciation. Review of Palaeobotany and Palynology 212, 60-84. DOI 10.1016/j.revpalbo.2014.10.005

Ramos, V.A. 1999. Las provincias geológicas del territorio argentino, 41-96. In CAminos, R. (ed.) Geología Argentina, Instituto de Geología y Recursos Minerales, SEGEMAR, Buenos Aires, Anales 29.

Ramos, V.A. \& Corra, B. 2008. Las provincias geológicas de Jujuy, 11-15. In CoirA, B. \& ZAPpettini, E.O. (eds) Geología y Recursos Naturales de la Provincia de Jujuy, XVII Congreso Geológico Argentino, Jujuy, Relatorio.

Rao, R.I., Moya, M.C. \& Hünicken, M.A. 2000. Conodontes en la Formación Las Vicuñas (Tremadociano temprano), Puna occidental argentina. Ameghiniana (Suplemento) 37(4), 13-14. 
Robin, L., Cocks, M. \& Torsvik, T.H. 2004. Mayor Terranes in the Ordovician. In WebBy, B.D., Paris, F., Droser, M.L. \& Percival, I.G. (eds) The Great Ordovician Biodiversification Event, Columbia University Press, New York 2, 61-67. DOI 10.7312/webb12678-006

Rubinstein, C.V. \& VACCARI, N.E. 2004. Cryptospore assemblages from the Ordovician-Silurian boundary in the Puna, north-west Argentina. Palaeontology 47, 1037-1061. DOI 10.1111/j.0031-0239.2004.00388.x

Rubinstein, C.V., de la Puente, G.S., Delabroye, A. \& Astini, R.A. 2016. The palynological record across the Ordovician/ Silurian boundary in the Cordillera Oriental, Central Andean Basin, northwestern Argentina. Review of Palaeobotany and Palynology 224, 14-25.

DOI 10.1016/j.revpalbo.2015.06.011

Samuelsson, J. \& Verniers, J. 2000. Ordovician chitinozoan biozonation of the Brabant Massif, Belgium. Review of Palaeobotany and Palynology 113, 105-129.

DOI 10.1016/S0034-6667(00)00055-5

Schallreuter, R. 1963. Neue Chitinozoen aus ordovizischen Geschieben und Bemerkungen zur Gattung Illichitina. Paläontologische Abhandlungen 1(4), 391-405.

Schlagintweit, O. 1943. La posición estratigráfica del yacimiento de hierro de Zapla y la difusión del horizonte glacial de Zapla en la Argentina y Bolivia. Revista de Minería Argentina 13, 115-127.

Sommer, F.W. \& VAn Boekel, N.M. 1964. Quitinozoários do Devoniano de Goiás. Anais da Academia Brasileira de Ciências 36, 423-431.

StARCK, D. 1995. Silurian-Jurassic stratigraphy and basin evolution of northwestern Argentina, 251-267. In TANKARD, A.J., SuÁrez, S.R. \& Welsink, H.J. (eds) Petroleum Basins of South America. American Association of Petroleum Geology, Memoir 62.

Steemans, P., Higgs, K., Wellman, C.H. 2000. Cryptospores and trilete spores from the Llandovery, NYYM-2 borehole, Saudi Arabia, 92-115. In Al-HaJRi, S. \& Owens, B. (eds) Stratigraphic palynology of the Palaeozoic of Saudi Arabia. GeoArabia Special Publication 1.

Strother, P.K., Taylor, W.A., Van de Schootbrugge, B., LeAnder, B.S. \& Wellman, C.H. 2019. Pellicle ultrastructure demonstrates that Moyeria is a fossil euglenid. Palynology 44(3), 461-471.

DOI 10.1080/01916122.2019.1625457

Thusu, B., Rasul, S., Paris, F., Meinhold, G., Howard, J.P., Abutarruma, Y. \& Whitham, A.G. 2013. Latest Ordovicianearliest Silurian acritarchs and chitinozoans from subsurface samples in Jebel Asba, Kufra Basin, SE Libya. Review of Palaeobotany and Palynology 197, 90-118.

DOI 10.1016/j.revpalbo.2013.05.006

Turner, J.C.M. 1960. Estratigrafía de la sierra de Santa Victoria y adyacencias. Academia Nacional de Ciencias de Córdoba, Boletín 41, 163-196.

Turner, J.C.M. 1970. The Andes of Northwestern Argentina. Geologische Rundschau, Stuttgart 59(3), 1028-1063. DOI 10.1007/BF02042283

Underwood, C.J., Deynoux, M. \& Ghienne, J.-F. 1998. High palaeolatitude (Hodh, Mauritania) recovery of graptolite faunas after the Hirnantian (end Ordovician) extinction event. Palaeogeography, Palaeoclimatology, Palaeoecology 142, 91-105. DOI 10.1016/S0031-0182(98)00070-4

Vaccari, N.E., Toro, B.A., de la Puente, G.S. \& Rubinstein, C.V. 2010. Nuevos aportes al conocimiento del Paleozoico inferior del área de Salar del Rincón, Puna occidental, Argentina. $X$ Congreso Argentino de Paleontología y Bioestratigrafia \& VII Congreso Latinoamericano de Paleontología, La Plata, Resúmenes 40, p. 56.

Vandenbroucke, T.R.A., Rickards, B. \& Verniers, J. 2005. Upper Ordovician Chitinozoan biostratigraphy from the type Ashgill Area (Cautley district) and the Pus Gill section (Dufton district, Cross Fell Inlier), Cumbria, Northern England. Geological Magazine 142(6), 783-807.

DOI 10.1017/S0016756805000944

Vandenbroucke, T.R.A., Gabbott, S.E., Paris, F., Aldridge, R.J. \& Theron, J.N. 2009. Chitinozoans and the age of the Soom Shale, an Ordovician black shale Lagerstätte, South Africa. Journal of Micropalaeontology 28, 53-66.

DOI 10.1144/jm.28.1.53

Vandenbroucke, T.R.A., Hennissen, J., Zalasiewicz, J.A. \& VERNIERS, J. 2008. New chitinozoans from the historical type area of the Hirnantian and additional key sections in the Wye Valley, Wales, UK. Geological Journal 43, 397-414.

DOI 10.1002/gj.1109

Webby, B.D., Cooper, R.A., Bergström, S.M. \& Paris, F. 2004. Stratigraphic framework and time slices, 41-47. In Webby, B.D., Paris, F., Droser, M.L. \& Percival, I.G. (eds) The Great Ordovician Biodiversification Event, Columbia University Press, New York 2. DOI 10.7312/webb12678

Wellman, C.H., Steemans, P. \& Miller, M.A. 2015. Spore assemblages from Upper Ordovician and lowermost Silurian sediments recovered from Qusaiba-1 shallow core hole, Qasim region, Central Saudi Arabia. Review of Palaeobotany and Palynology 212, 111-126.

DOI 10.1016/j.revpalbo.2014.09.003 